\title{
Oxidative Stress in DNA Repeat Expansion Disorders: A Focus on NRF2 Signaling Involvement
}

\author{
Piergiorgio La Rosa ${ }^{(}$, Sara Petrillo, Enrico Silvio Bertini $(\mathbb{D}$ and Fiorella Piemonte *(i) \\ Unit of Muscular and Neurodegenerative Diseases, Bambino Gesù Children's Hospital, IRCCS, 00146 Rome, \\ Italy; piergiorgio.larosa@opbg.net (P.L.R.); sara.petrillo@opbg.net (S.P.); enricosilvio.bertini@opbg.net (E.S.B.) \\ * Correspondence: fiorella.piemonte@opbg.net; Tel.: +39-06-6859-2102
}

Received: 10 April 2020; Accepted: 27 April 2020; Published: 1 May 2020

\begin{abstract}
DNA repeat expansion disorders are a group of neuromuscular and neurodegenerative diseases that arise from the inheritance of long tracts of nucleotide repetitions, located in the regulatory region, introns, or inside the coding sequence of a gene. Although loss of protein expression and/or the gain of function of its transcribed mRNA or translated product represent the major pathogenic effect of these pathologies, mitochondrial dysfunction and imbalance in redox homeostasis are reported as common features in these disorders, deeply affecting their severity and progression. In this review, we examine the role that the redox imbalance plays in the pathological mechanisms of DNA expansion disorders and the recent advances on antioxidant treatments, particularly focusing on the expression and the activity of the transcription factor NRF2, the main cellular regulator of the antioxidant response.
\end{abstract}

Keywords: DNA repeat expansion disorders; NRF2; oxidative stress; FXTAS; fragile X syndrome; Friedreich's ataxia; myotonic dystrophy; spinocerebellar ataxia; Huntington's disease; spinal and bulbar muscular atrophy

\section{Introduction}

Microsatellites are stretches of DNA abundantly interspersed in the genome of prokaryotes and eukaryotes [1,2], including humans, where they account for the $3 \%$ of the genome [3]. Their structure consists of short, tandemly repeated duplications of 1-6 base pairs, spanning between 20-100 bases [4] and primarily consisting of mono- and dinucleotides, although tri-, tetra-, penta-, and hexa-nucleotides microsatellite classes are present $[4,5]$. Their location is ubiquitous, occurring both in protein-coding as well as in non-coding DNA regions, with preference for the latter [6], and their functions range among several biological regulatory processes [7], including alternative splicing [8], transcription start/end site selection [9,10], nucleosome packaging [11], and methylation [12]. One of the most peculiar characteristics of microsatellites is their tendency to mutate. While $10^{-9}$ is the rate of mutations occurring in non-repetitive region of the DNA, microsatellite mutation rate ranges between $10^{-2}$ and $10^{-6}[13,14]$. Because of this, microsatellites are highly polymorphic, as the number of the repeats in a given locus is relatively unstable and frequently varies between individuals [15]. Due to this feature, deregulated microsatellite expansions are widely known to be the triggering cause of many neurological and neuromuscular diseases and, to date, more than 30 disorders are known to be caused by aberrant expansion of repetitive DNA sequences [16]. Although trinucleotides repeats, in particular GAA, CGG, CAG, and CTG, are commonly known to be responsible for the pathologic manifestation of nucleotide expansion disorders, also tetra- and penta-nucleotides expansions are disease causing [17], thus these diseases are collectively classified as disorders of DNA unstable repeat expansions [18]. Some peculiarities join this variegated group of pathologies: (i) The disease-causing expansion repeats are more unstable in the affected population, with a higher tendency to expand or to contract with respect to 
the polymorphic repeats of normal people, even if contraction events are rarer [16]. This also occurs as the repeats reach the threshold limit between a normal condition and the pathological state. Thus, even in unaffected families, de novo mutations can determine clinical manifestations [19]. (ii) The dynamic changes in the length of expansions are so marked that differences among patients, as well as in different tissues of the same affected proband, are common [16]. (iii) The more the expansions are transmitted from generation to generation, the earlier the disease symptoms appear in the newly affected individuals, a phenomenon known as clinical anticipation [20-22]. (iv) In most disorders, the length of repeat expansions influences the phenotype severity of affected individuals [23-29]. Consequently, different defects for a given disease can be expressed among patients, including onset of symptoms and co-morbidities. For example, the incidence of diabetes in Friedreich's ataxia (FA) ranges between $8-32 \%$ of patients [30-32], but the risk of developing is directly correlated to the number of GAA repeats in the frataxin (FXN) gene [33]. In the same way, in myotonic dystrophy (DM), patients carrying small CTG repeats (i.e., between 50-99) are asymptomatic or develop mild defects, such as cataracts, while a severe phenotype occurs in patients with 100-200 repeats [34].

Beside these common features, a high grade of diversity characterizes DNA expansion disorders, as the DNA expanded tracts can affect genes encoding proteins with different roles. Therefore, three different classes have been distinguished, by assembling disorders on the basis of which defects arise from expansions. The first class groups the diseases that are determined by a protein loss of function and are inherited by autosomal recessive or x-linked manner [19]. Typical examples are Fragile X (FXS) or FA, where CGG or GAA repeats determine the loss of the expression of the fragile $X$ mental retardation protein (FMRP) and FXN, respectively $[35,36]$. The second group belongs to disorders characterized by an autosomal dominant inheritance and in which a protein gain of function occurs [18]. PolyQ diseases, for instance, are determined by CAG expansions in the coding region of 9 distinct genes that lead to the formation of glutamine residues in the final peptide of their encoded product [37]. PolyQ tracts exert a toxic effect mainly by causing aberrant nuclear and cytoplasmic protein aggregation and trapping transcription factors [38,39], chaperons, and proteins belonging to the ubiquitin-proteasome system (UPS) [40]. The third group of disorders are characterized by gain of function involving the transcribed RNA. DM1 and DM2 are respectively caused by the aberrant insertion of CTG and CCTG expansion repeats in the $3^{\prime}$ untranslated region (UTR) of dystrophin myotonic protein kinase (DMPK) [41] and in the first intron of zinc-finger protein 9 (ZNF9) [42]. Similarly, the CGG triplet expansion in FMR1 gene, ranging between 60-200 triplets, causes the fragile $X$-associated tremor ataxia syndrome (FXTAS) [43]. The pathogenic activity, both in DM and in FXTAS, lies on of the respective expanded mRNA molecules, which are able to sequestrate RNA binding proteins, such as muscleblind-like (MBNL) proteins in DM1, determining splicing alterations and impairments in protein expression [44-47].

Oxidative stress has been widely reported to play a prominent role in neurodegenerative diseases [48,49], including disorders caused by DNA expansion repeats (Figure 1). Here, we report the most recent evidences connecting ROS imbalance and DNA expansion disorders, with particular emphasis to the pathway primarily involved in the regulation of cellular antioxidant response, the NF-E2 p45-related factor 2 (NRF2) signaling pathway. 


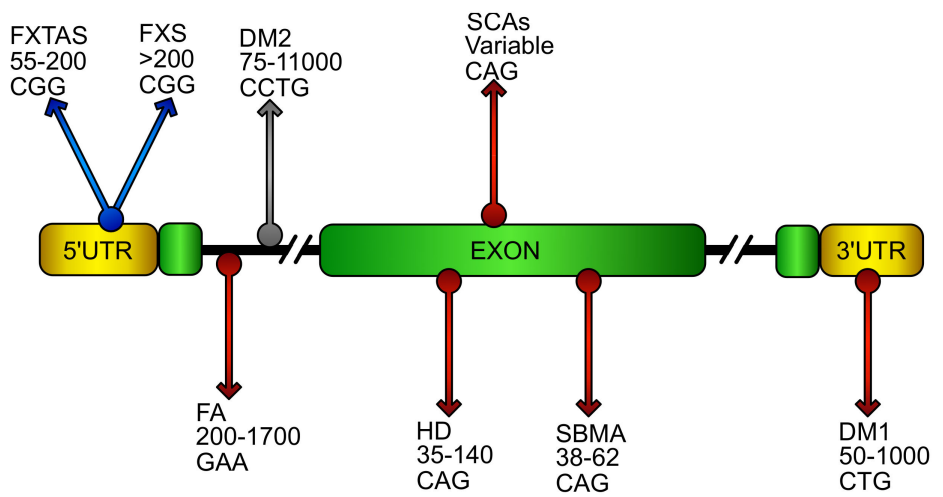

Figure 1. Putative location and sequence of DNA expansions in repeat disorders. Schematic representation of an ideal gene showing DNA repeat expansions that cause diseases. Name of the relative disorder, number of pathogenic repeats, and its sequence are reported in the gene region were the repeats stem in the pathology. The grey arrow represents pathology where oxidative stress has been poorly investigated. Blue arrows characterize diseases with oxidative stress contributions. Red arrows identify pathologies in which NF-E2 p45-related factor 2 (NRF2) involvement has been reported. (FXTAS, fragile X-associated tremor ataxia syndrome; FXS, fragile X syndrome; FA, Friedreich's ataxia; DM1/DM2 myotonic dystrophy; HD, Huntington's disease; SCAs, spinocerebellar ataxias; SBMA, spinobulbar muscular atrophy).

\section{Oxidative Stress and Cellular Responses}

Oxidative stress occurs when the balance between ROS production and elimination cannot be maintained in the cell, thus determining damage on lipids, proteins, and nucleic acids, ultimately leading to cell death $[50,51]$. Oxidative stress can be determined by exogenous (i.e., UV light or chemicals) and endogenous factors [52], as mitochondrial metabolism and NADH oxidase activity, the major endogenous ROS sources [53,54]. ROS production and elimination are tightly controlled in the cell, as aerobic organisms use $\mathrm{O}_{2}$ molecules in redox reactions needed for energy demands and oxygen byproducts (superoxide anion, $\mathrm{O}_{2}{ }^{-}$, hydrogen peroxide, $\mathrm{H}_{2} \mathrm{O}_{2}$, hydroxyl radical, $\mathrm{HO}^{*}$ ) to transduce regulatory signals [55-58]. Thus, an efficient antioxidant cellular machinery is essential to mitigate adverse effects and to permit a correct signaling cascade modulation. This variety of endogenous defenses consists of antioxidant enzymes, including superoxide dismutases (SODs) [59], catalase [60], glutathione peroxidases (GPXs) [61], and scavenger molecules, such as glutathione (GSH), ubiquinol (CoQ10), uric acid, and others [62].

GSH, in particular, represents the most important endogenous antioxidant for its dual function, as a direct ROS scavenger $[63,64]$ and as cofactor in reactions catalyzed by antioxidant enzymes (e.g., glutathione reductase, GR, GPXs) [65] and in those involved in the elimination of xenobiotics (glutathione-S transferases, GSTs) [66]. The GSH synthesis occurs in 2 steps, the first uses cysteine and glutamate as substrates and is catalyzed by the glutamate cysteine ligase (GCL), while the second, catalyzed by the glutathione synthetase (GSS), binds glycine to the pre-synthesized dipeptide $[67,68]$.

Under physiological conditions, a basal expression of this antioxidant machinery is available in cells. However, to promptly answer to redox imbalance that ranges from mild to high pathologicinduced oxidative stress $[69,70]$, cells evolved the transcription-independent activation of NRF2, able in turn to modulate the expression of several antioxidant enzymes (SODs, catalase, GPXs), to ensure the GSH synthesis (by GCL expression) and to reduce toxic quinones by the action of $\mathrm{NAD}(\mathrm{P}) \mathrm{H}$ : quinone oxidoreductase (NQO1) [70-72].

\section{NRF2 Pathway and Its Regulation}

$\mathrm{NRF} 2$ is a transcription factor belonging to the cap ' $\mathrm{n}$ ' collar (CNC) basic leucine zipper (bZip) proteins $[73,74]$. In the nucleus, it dimerizes with the small musculoaponeurotic fibrosarcoma (sMAF) proteins, particularly with F, G, and K isoforms [75,76]. The NRF2-sMAF heterodimer binds to specific 
16 base long DNA stretches (the antioxidant responsive elements, ARE), acting as enhancer for gene transcription [77]. NRF2 is able to regulate the expression of at least 250 genes [78] and, besides being the master regulator of cellular antioxidant defense, its activity participates to the modulation of different cellular processes, including metabolism, survival, differentiation, inflammation, mitochondrial biogenesis, and mitophagy [69,78-84]. For this reason, the NRF2 activity and expression are subjected to a tight and fine-tuned control mechanism, to avoid unwanted gene expression upregulation and, at the same time, determining a fast response in case of need. Upon oxidative stress, the induction of NRF2 occurs by regulating its stability and localization in the cell [72], and modulating the amount of its mRNA transcript $[81,85]$.

Under physiological condition, NRF2 has a short half-life, spanning between 15-40 min, and its cellular localization is restricted to the cytoplasm [86]. Soon after translation, NRF2 interacts with the ubiquitin ligase adaptor KEAP1 (Kelch-like ECH-associated protein 1) that sequesters the transcription factor and mediates its proteasomal degradation [87]. In parallel, free NRF2 can be phosphorylated by the GSK3 $\beta$ kinase, which increases the NRF2 proteasomal-mediated turnover $[71,86]$. These two mechanisms work in conjunction to regulate NRF2 activity, in response to different cellular cues. Under redox imbalance, the KEAP1-NRF2 interaction is disrupted, as result of ROS-induced conformational changes of KEAP1 [88]. Conversely, the activation of growth factor receptors determines the AKT/PI3K-induced inhibitory phosphorylation of GSK3 $\beta$, thus allowing NRF2 accumulation [89]. This regulatory system points to the NRF2/ARE axis as one of the most important signaling pathway in cells. Indeed, being ARE sequences implicated in the regulation of more than $1 \%$ of human genes [86], impairments of NRF2 signaling network may interfere with multiple cellular processes and determine redox imbalance, a condition commonly encountered in cancers [90-92] and in neurological disorders. Re-establishing NRF2 signaling homeostasis can be essential to improve the pathological phenotypes, especially in neurodegenerative diseases [93-95].

Recent evidences increasingly highlight a dual role of NRF2 in the diseases' pathogenesis. In cancer, for instance, the activation of Nrf2 appears correlated with progression and chemo-resistance, and its downregulation has attracted growing attention as alternative cancer therapy [96]. Several studies have clearly demonstrated that the hyper-activation of the NRF2 pathway may create an environment favoring the survival of malignant cells, protecting them against oxidative stress, chemotherapeutic agents, and radiotherapy $[97,98]$. Indeed, although a transient NRF2 activation in response to stress may be beneficial for health, a persistent induction can confer therapeutic resistance in cancer cells and more aggressive tumorigenicity, leading to poor prognoses in patients. In this light, the inhibition of NRF2 is a promising therapeutic approach in cancer and NRF2 inhibitors are being actively developed [99]. Contrariwise, NRF2 appears inhibited in many neurodegenerative disorders, such as Huntington's disease, Alzheimer's disease, amyotrophic lateral sclerosis, multiple sclerosis and FA, where its activation has been proven mitigating pathogenic processes by upregulating antioxidant defenses, decreasing inflammation, and improving mitochondrial function [80,100-103]. Therefore, a dual face of Nrf2 in cancer and neurodegenerative diseases has to be recognized, making its role in the pathogenesis' mechanisms even more attractive.

\section{Oxidative Stress in Loss of Function DNA Expansion Disease}

\subsection{Friedreich's Ataxia (FA)}

(FA) is an autosomal recessive neurodegenerative disease caused by a homozygous GAA trinucleotide repeat expansion in the first intron of the FXN gene, encoding for the mitochondrial FXN protein $[36,104]$. The GAA repeated expansions cause histones deacetylation and abnormal DNA conformation, leading to decreased mRNA levels and FXN amount [105]. FA is clinically characterized by progressive ataxia, diabetes, cardiomyopathy, skeletal deformations, altered central and peripheral nervous system with lesions in the dorsal root ganglia, dentate nuclei of the cerebellum, corticospinal tracts, and sensory peripheral nerves [106-108]. Actually, the FXN function is still unclear, although it 
is well known to be involved in iron-sulphur cluster biogenesis and in heme biosynthesis. The FXN deficiency increases the mitochondrial iron content, altering activities of iron-sulphur (Fe-S) cluster enzymes in mitochondria and causing oxidative stress in affected tissues [109-111]. Oxidative stress is a leading hypothesis in the pathogenesis of FA, since the identification of the gene in 1996 and later supported and confirmed by several studies in human and mouse FA models [112-115].

Several studies have demonstrated an impairment of the NRF2 pathway in FA [116-119] and alterations of systemic redox markers have been evidenced in patients. An increased oxidative damage on nuclear and mitochondrial DNA has been found in peripheral blood cells, together with high levels of plasma malondialdehyde and of urine 8-hydroxy-2-desoxiguanosine [120,121]. A decrease of glutathione levels and of antioxidant enzymes activities (SOD and GST) have been also reported in fibroblasts and in blood of patients [122,123]. Recently, lipid peroxidation and ferroptosis have also been suggested as responsible for the FA pathophysiology [124-126]. It is important to note that two ferroptosis-triggering enzymes (GPX4 and cysteine/glutamate transporter system, xC-/xCT) are downstream targets of NRF2 [127]. For all these findings, NRF2 has recently attracted attention for novel therapeutic strategies in FA [72,94,128,129]. Among the main pharmacological NRF2 activators, we can mention the Sulforaphane (SFN), a natural blood-brain-barrier permeable antioxidant, and the dimethyl fumarate (DMF), an ester of fumaric acid recently approved for the treatment of multiple sclerosis [130-133] and promising for adrenoleukodystrophy [134]. The efficacy of these NRF2 inducers has been verified on several FXN deficient models [81,85,135], where they significantly increased NRF2 mRNA levels [85], re-balanced the GSH/GSSG ratio [85,135], and up-regulated the FXN gene expression [85,135-137] (Figure 2).

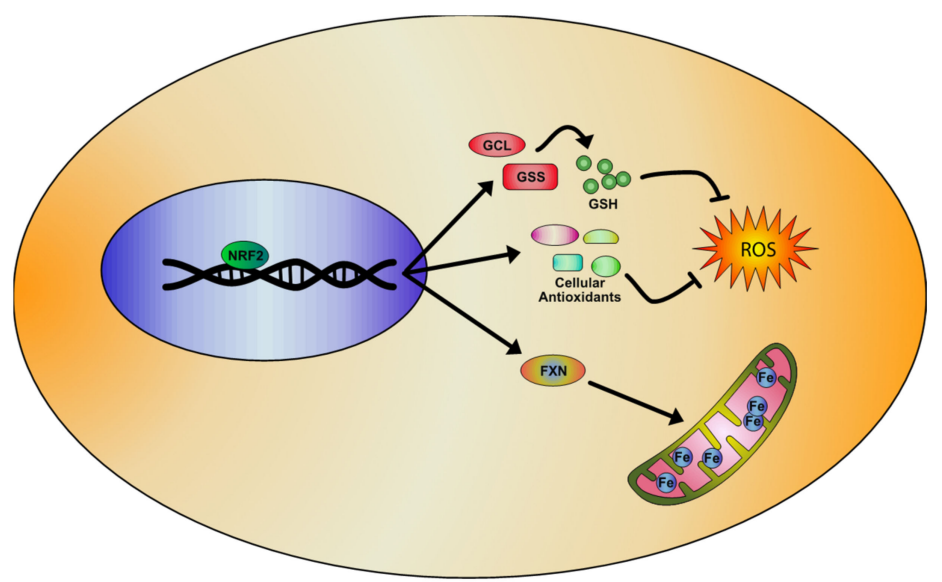

Figure 2. Representative model of the NRF2 signaling pathway activation in Friedreich's Ataxia (FA), based on literature evidences. NRF2 inducers determine the activation of antioxidant genes transcription and the upregulation of enzymes involved in the regulation of glutathione (GSH) expression, rebalancing the unpaired GSH/GSSG ratio and reducing oxidative stress and lipid peroxidation. Importantly, NRF2 also increases frataxin $(\mathrm{FXN})$ levels, thus partially rescuing the mitochondrial defects observed in FA pathology.

Currently, clinical FA trials are focused on improving mitochondrial function and reducing oxidative stress [138]. Idebenone (Raxone ${ }^{\circledR} /$ Catena $\left.{ }^{\circledR}\right)$, for instance, is proven to be effective on the mitochondrial function. But, despite an initial optimism on its cardiac impact, the neurological benefit in FA is still under evaluation [139-141]. RTA408 (Omaveloxolone), a specific NRF2 inducer [142], is currently being tested in a 12 months placebo-controlled trial (www.clinicaltrials.gov). EPI-743 (vatiquinone), another highly promising drug for FA [143], was approved in 2011 for children with genetically confirmed inherited respiratory chain diseases, but still not clinically tested in FA, although it has been proven to activate NRF2 and increase the expression of FXN in fibroblasts of FA patients [85]. 


\subsection{X-Fragile (FXS)}

FXS syndrome is caused by the absence or deficiency of FMRP, the gene product of FMR1 [144]. In most cases, CGG trinucleotide expansions at the FMR1 promoter determine its transcriptional silencing, giving rise to the disease [145]. More than 200 CGG repeat expansions determine the FXS phenotype, while premutation alleles, bearing 55-200 CGG tracts, are recognized to cause FXTAS. Mutations or deletions in the FMR1 gene have been also reported in FXS patients [146,147], as well as mosaicisms of repeat length (i.e., some cells harboring the full mutation in one allele and others containing the premutation allele), or of methylation [148]. FXS represents the most common form of inherited intellectual disability [145], affecting 1:5000 males and 1:4000-8000 females [144], often associated with autism spectrum disorder comorbidities, estimated in about 50\% patients [149]. Clinical FXS manifestations include language development delays, hyperactivity, anxiety, and physical dysmorphic features $[150,151]$. Females' phenotype is usually less severe, due to the presence of the second X chromosome that can restore FMRP expression in approximately $50 \%$ of cells [152].

FMRP is a RNA-binding protein forming a ribonucleoproteic complex that associates to polyribosomes and regulates mRNA metabolism, acting as a translation suppressor [153]. Its expression is particularly high in neurons, where it shuttles between nucleus and axons or dendrites $[154,155]$ and carries out its function, especially at postsynaptic sites, where it transports mRNA cargos $[156,157]$ and where its activity is tightly regulated by synaptic receptors [158-162]. The absence of FMRP mostly determines an increase of translation rate of its targets [163-166] and impairs the synaptic development and plasticity in specific brain areas [158,167].

Oxidative stress in FXS has been suggested by a number of indirect evidences: (i) aging-dependent oxidative stress increase is responsible for impairments in long-term (LTP) potentiation in the hippocampus [168], a condition described in FXS [158,169]. (ii) Anxiety and autism, which are strongly linked to ROS impairments, are common conditions in the pathology [170-172]. (iii) As in Alzheimer's disease, where oxidative stress is a recognized contributing factor in progression and pathogenesis of the disorder [48], in models of FXS amyloid beta (A $\beta$ ) expression is increased, probably as a consequence of FMRP-mediated dysregulation of amyloid precursor protein (APP) translation [173]. Despite these evidences, only a moderate increase of oxidative stress has been documented in FXS. Biochemical markers of oxidative stress have been detected in the brain of Fmrp1 KO mice, where increased ROS levels, high content of lipid peroxidation byproducts (i.e., thiobarbituric acid reactive substances, TBARS), enhanced carbonyl protein content, and imbalance of the GSH/GSSG redox ratio have been found in 2-4 months old mice, although these markers appeared to normalize over time [174]. Moreover, although FMRP favors the translation of SOD1 mRNA $[175,176]$ and, consequently, Fmr1 null mice display a strongly reduced expression of SOD1 [176], to date, definitive proofs on oxidative stress depending on SOD1 decreased activity are still lacking in FXS. These apparent inconsistencies could be related to an indirect redox regulation operated by FMRP on NRF2. Indeed, the lack of FMRP increases the synthesis and the activity of the small Rho GTPase RAC1 [177], which exerts a role in ROS modulation and in the inflammatory response [178] by inducing NRF2 and up-regulating HO-1 expression [177]. RAC1 is known to participate in the activation of PI3K and MAPKs signaling pathways $[179,180]$, thus suggesting that the modulation of NRF2 activity may depend on the RAC1 mediated AKT/PI3K-induced inhibitory phosphorylation of GSK3 $\beta$ [89,181], possibly rebalancing oxidative and inflammatory responses in FXS [177].

\section{Oxidative Stress in CAG/polyQ Diseases}

\subsection{Spinobulbar Muscular Atrophy (SBMA)}

SBMA, also known as Kennedy's disease, is a neuromuscular X-linked disorder, which exclusively affects adult males [182]. Patients display progressive cramps, fasciculation, tremor, and weakness of skeletal muscles (especially bulbar, facial, and limb ones) [183], together with a mild androgen insensitivity syndrome (AIS) and sensory loss $[184,185]$. SBMA is due to spinal and bulbar motor 
neurons death, triggered by an expansion of more than 38 glutamine residues in the androgen receptor (AR) protein [186], a ligand activated transcriptional factor that mediates the cellular effects of the sex hormone testosterone and its metabolites [187]. The pathogenic mechanism in SBMA is unique respect to the other polyQ diseases. Nuclear and cytoplasmic inclusions of poliQ AR, UPS components, heat shock proteins (HSPs), and AR coactivators can be found in SBMA [188,189], however, other mechanisms participate to the pathogenicity of this disorder. PolyQ AR retains most of its functionality, but the region in which glutamine expansion occurs localizes in the N-terminal domain that is responsible for multiple protein-protein interactions [190]. This lead to partial loss of transcriptional activity [191], sequestration of transcription activators [192], and block of the AR-dependent non genomic signaling cascades [189]. Moreover, the pathogenic activity of polyG expanded AR seems to heavily depend on its ligands. Indeed, females homozygous for glutamine expanded AR display mild sings of SBMA [193] and studies in SBMA animal models demonstrated their androgen dependence $[194,195]$. Moreover, it has been proposed that WT AR signaling could play a role in the regulation of the expression of neurotrophins and growth factors known to support neuronal survival [182,196], a function that should be lost in the mutant receptor. Low expression of GDNF, for instance, was encountered in SBMA patients [197] and GDNF, IGF-1, and VEGF reduced expression was assessed in mouse models of the pathology [198,199].

Part of the SBMA pathogenic mechanism could be explained by increased ROS levels [200] and mitochondrial dysfunction [201]. Under physiological conditions, AR regulates the expression of several nuclear- and mitochondrial-DNA encoded proteins [202]. Thus, in cells expressing polyQ AR, numerous genes implicated in mitochondrial function are altered [200]. Moreover, mutant AR has been found to associate with the mitochondria in MN-1 cells, where it activates the intrinsic apoptotic pathway [200], and, in HeLa cells transfected with AR receptor bearing 48 glutamine expansions, mitochondria were sequestered in polyQ AR inclusions [203]. Although the toxicity of cytoplasmic AR aggregates has been questioned, [204,205] and mitochondrial sequestration was not found in polyQ AR expressing NSC34 motor neurons [206], mutant AR aggregates-mediated impairment of mitochondria transport along the neurites has been hypothesized in SBMA [206]. Another cause of mitochondrial impairment could be the androgen-dependent association of polyQ AR with the respiratory chain enzyme cytochrome c oxidase subunit $\mathrm{Vb}(\mathrm{COXVb})$, that could be trapped in mutant AR aggregates, interfering with the physiological function of oxidative phosphorylation [207]. It is important to underline that numerous cellular antioxidants are downregulated in SBMA, including proteins belonging to the pathway regulated by NRF2 (SODs, catalase [200], NQO1, and GPX). The expression of NRF2 itself was deeply reduced in motor neurons of mice carrying 100 glutamine expansions in AR with respect to the non-pathogenic 20 polyQ repeats-containing AR mice [208], and in MN-1 cells expressing the mutant AR [200]. Interestingly, some studies attempted to correct protein misfolding-induced aggregates by using curcumin, an antioxidant polyphenol whose activity was neuroprotective $[209,210]$. Curcumin treatment has been demonstrated to slow the protein aggregation [211] and to induce NRF2 activity [212,213]. A curcumin analog, ASC-J9, tested in cells and in a mouse model of SBMA, demonstrated beneficial effects on mutated AR aggregates, motor impairments, muscular atrophy, and VEGF expression [214]. Another curcumin analog, ASC-JM17, has been tested on cultured SBMA cells and has been found to activate NRF2 and its signaling pathway, determining the transcription of its target genes, including NQO1, HO-1, catalase, and GCL [215]. These evidences support a promising role for this class of molecules to reverse multiple SBMA pathogenic defects.

\subsection{Huntington's Disease (HD)}

Huntington's disease (HD) is a progressive, autosomal dominant neurodegenerative disease with defects in the striatum, cerebral cortex, and thalamus [216,217]. The HD disorder is caused by the abnormal expansion of the nucleotide triplet CAG in the gene coding for the protein huntingtin [218]. In the huntingtin gene (HTT) of healthy subjects, the number of trinucleotides CAG repeats varies 
from 1 to 34, while in HD patients, the CAG triplet expansion ranges between 35-140 repetitions [219]. Clinical features of HD include progressive motor dysfunction, psychiatric disturbance, cognitive decline, dystonia, bradykinesia, and dementia, ultimately leading to death within approximately 15-20 years from the age of onset [220]. The genetic abnormality in the HD gene leads to the formation of a mutant huntingtin protein $(\mathrm{mHtt})$, which is normally involved in the vesicle transport and represents a scaffold for the autophagic machinery [221,222]. The mutant protein exhibits toxic properties, leading to protein aggregation, transcriptional dysregulation, defective energy metabolism, chronic inflammation, and oxidative stress [223-226]. Inflammation, mitochondrial dysfunction, and oxidative stress are some of the key pathways persistently abnormal in mouse models of HD and in autoptic tissues of patients.

Several pharmacological HD mice models have been developed, resembling defective neuro-motor functions described in human HD patients [227-230] and supporting oxidative damage as a pathogenic mechanism underlying neurodegeneration in this disease [231,232]. Increased markers of oxidative stress, mitochondrial failure, and chronic inflammation have been found in brain tissue of HD patients. High levels of malondialdehyde, 8-hydroxy-deoxyguanosina, and carbonyls, and lower levels of GSH, SOD1, and GPX, have been detected in plasma and red blood cells of patients [233,234]. Additionally, mitochondrial DNA damage, low levels of oxidative phosphorylation enzymes, and iron-mediated mitochondrial impairment have been shown in autoptic brain tissues of patients [231,235]. In addition, increased amounts of circulating pro-inflammatory cytokines have been reported in patients, whose levels correlated to the severity of the disease [234]. Numerous studies have been focused to reduce oxidative damage in $\mathrm{HD}$ by using antioxidants (alpha-tocopherol, CoQ10, vitamin E, vitamin C, $\mathrm{N}$-acetylcysteine (NAC), lipoic acid [236-242]). Nevertheless, these compounds have shown a moderate effectiveness in counteracting oxidative stress in mouse models, thus leading to hypothesize that a pharmacological upstream activation of NRF2 should be required. Recently, the potent NRF2 inducer SFN has been tested, showing increased mHtt degradation and a significant reduction of cytotoxicity by the NRF2-mediated activation of the ubiquitin-proteasome system [243]. The SFN pre-treatement ameliorated behavioral impairments and reduced pro-inflammatory cytokines in the striatum of a 3-nitropropionic acid (3-NP) mouse model by attenuating neuroinflammation and oxidative stress [243]. High susceptibility to oxidative stress has been also found in human HD neural stem cells, where the genetic correction of the disease-causing mutation restored the redox balance [244]. The protective effect of NRF2 activation in HD patients has been further confirmed in primary monocytes, where the NRF2 induction inhibited the release of pro-inflammatory cytokines (IL-6, IL-1, IL-8, and TNF $\alpha$ ) [244]. As in other neurodegenerative diseases, also in HD has been hypothesized a role for ferroptosis in the pathogenic mechanism, mainly as a consequence of increased iron levels that were detected in brain regions of patients [235,245]. Therefore, even in HD, NRF2 can represent a strategic therapeutic target, for its ability in preventing iron overload and regulating ferroptosis-related genes expression [246]. DMF, for instance, exerted beneficial effects on survival and motor functions in R6/2 and YAC128 models of $\mathrm{HD}$, preserving the neuronal integrity in striatum and motor cortex, and slowing degeneration [247]. Additionally, gintonin (GT), a ginseng-derived lysophosphatidic acid receptor ligand, was effective on the NRF2 pathway in the striatum of 3-NPA mice, by protecting the mitochondrial function and reducing the expression of inflammatory mediators (cytokines, COX-2, and iNOS) [248].

\subsection{Spinocerebellar Ataxias (SCAs)}

SCAs comprise more than 40 disorders, all characterized by progressive degeneration of the cerebellum, which determines abnormal coordination and gait impairments [249]. Clinical features have been used to initially subdivide these disorders. Indeed, almost all forms of SCAs are characterized by cerebellar degeneration, with involvement of Purkinje and granule cell layers and neurons of deep cerebellar nuclei [250,251]. However, other regions of the brain can be affected. In all polyQ SCAs, for example, with the exception of SCA6 where Purkinje neurons are exclusively implicated, brainstem is involved [251,252]. Moreover, many forms of SCAs share clinical signs on basal ganglia, spinal cord, cerebral cortex, and peripheral nerves, while epilepsy is restricted to 
SCA10, and pigmentary retinal degeneration only occurs in SCA7 [251-253]. A genetic classification has been developed for these disorders based on heritance (i.e., autosomal dominant, autosomal recessive, X-linked, and mitochondrial) [254] and type of mutation (microsatellite repeat expansion or point mutation [255]. Despite this, the gene or mutation responsible for many SCAs are currently unknown [253]. The pathogenic mechanism appears variegated even among the autosomal dominant forms of SCA. Indeed, while polyQ tracts encoded by CAG repeats are present in at least 7 disorders (SCA1, 2, 3, 6, 7, 17, and DRPLA), tri- penta- or hexanucleotide expansions, located in introns or in the $3^{\prime} \mathrm{UTR}$, occur in SCA8, 10, 12, 31, 36, and 37, determining an unclear pathogenic mechanism compatible with the generation of toxic mRNA or transcriptional silencing [18,255]. Only the polyQ SCAs were considered in this review, being the best characterized for their oxidative stress defects. PolyQ SCAs display a wide range of phenotypes due to the great instability of repeat expansion length, also responsible for the clinical anticipation reported for these disorders. This is most evident in the Machado-Joseph disease (SCA3), where the pathologic onset can occur in childhood, in middle-age, or have a late onset, depending on the expansion length. In people with smaller repeats, the disease can present as restless leg syndrome [251,256]. The physiological functions of the proteins responsible for SCAs are highly heterogeneous: ataxin 1, the protein mutated in SCA1, interacts in the nucleus with transcriptional regulators and with the splicing complex [257]; similarly, ataxin 7, TATA-binding protein (TBP) and atrophin 1, whose mutations are the underlying cause of SCA7, SCA17, and DRPLA, are involved in transcriptional regulation processes, but with different roles (e.g., activating or repressing function) and with different interactors [258-260]; ataxin 2 (SCA2) regulates translation, by the interaction with poly(a)-binding protein [261]; ataxin 3 (SCA3) is a de-ubiquitination enzyme [262]; Cav2.1 $\alpha 1 \mathrm{~A}$ (SCA6) is a subunit of the voltage dependent calcium channel [263].

Despite the functional heterogeneity and beside the partial loss of ataxin 1 function observed in SCA1 [264], in all these disorders, the proposed pathogenic mechanism is the same: polyQ expansions promote protein misfolding that results in aggregation [253]. This leads to defective interactions with common partners and determines impairment in shared cellular pathways leading to cerebellar neurons degeneration [265]. The aggregates grow by time, forming big inclusions that may represent a valid biomarker for the disease. However, a discrepancy has been evidenced, as the presence of protein aggregates has been often reported to correlate with neuronal survival rather than to cell death [251]. One hypothesis is that small CAG-expanded protein oligomers, produced at earlier steps of aggregation, are more toxic for the cell than larger ones [251]. As reported for other polyQ diseases, these inclusions are positive for the presence of transcription factors [192], as well as for proteins belonging to the quality control assessment (i.e., chaperons) and to the UPS system [266,267], suggesting that a major pathogenic route in these disorders consists in the derangement of the two cellular systems functioning in the clearance of damaged proteins [268]. In line with this, some studies reported that both polyQ Ataxin 1 and 7 fail to be degraded by the proteasome, as it occurs in normal conditions [269,270]. Moreover, due to its localization near the polyQ expanded tract, the function of the Jospephin domain, which mediates the de-ubiquitinating activity of ataxin 3, could be altered, impairing ataxin 3 association with the proteasome [271] and further exacerbating the activity of the UPS system [253].

Oxidative stress, mitochondrial impairments, and NRF2 involvement are widely reported in SCAs and, due to the fact that Purkinje neurons are among the most energy-demanding cellular types [272], it is not surprising that mitochondrial impairment in these disorders have been proposed to strongly contribute to the disease progression [273]. In the SCA1 mouse model, the mutant ataxin 1 has been found to sequester the high mobility group box1 complex (HMGB1), inhibiting its function [274] and determining the increase of mitochondrial DNA damage [275]. Successive studies performed in Sca1 ${ }^{154 \mathrm{Q} / 2 \mathrm{Q}}$ mice evidenced morphological mitochondria alterations, dysfunctional electron transport chain (ETC) enzyme activities, and increased oxidative damage [273]. Importantly, in young Sca ${ }^{154 \mathrm{Q} / 2 \mathrm{Q}}$ mice, that have not yet exhibited mitochondrial defects, the treatment with a quinone, which is able to modulate NRF2 nuclear translocation and activity (MitoQ) [276], is capable of delaying the onset of motor coordination defects [273]. Likewise, MitoQ administration to mice 
already displaying the pathologic deficits improves mouse phenotype [273]. In cultured SCA2 patient's fibroblasts, dysfunctions of mitochondrial network structure, alterations of antioxidant genes transcription and expression, increases of $\mathrm{O}^{-}$and $\mathrm{H}_{2} \mathrm{O}_{2}$ production, and impaired activities of ETC complex I, II, and III have been further evidenced [277], strongly connecting mitochondrial defects to ROS overload and oxidative stress. Despite many of these defects are rescued by treating SCA2 fibroblasts with $\mathrm{CoQ}_{10}$ [277], its clinical effect on a cohort of SCA1, 2, 3, and 6 patients is unclear. The drug administration was effective on clinical baseline outcome only in SCA1 and 3 patients, but it did not modify the progression of the disease in the 2 years follow-up trial [278]. Among SCAs, SCA3 is the most common [279] and the best characterized regarding the relationship among ROS, NRF2 imbalance, and neurodegeneration. In cells stably transfected with CAG expanded ataxin 3, a strong reduction of the GSH and GSH/GSSG ratio was observed. Paired to this, reduction of glutathione reductase (GSR), SOD, and catalase activities was reported, determining an increase of mitochondrial DNA damage, also assessed in SCA3 patient's blood [280]. Reduction of ETC complex II activity is reported in different SCA3 cellular and mouse models and in SCA3 human lymphoblastic cell lines, supporting an increase of ROS generation [281]. The redox imbalance has been demonstrated also in patients. A significant reduction of thiols levels, which include GSH and thioredoxins, has been described in a case-control study enrolling 7 patients with SCA3, although total polyphenols, lipid peroxides, and ROS levels appeared unchanged [282]. Nevertheless, a recent study performed on a larger number of SCA3 patients attested to an increase of ROS levels and the inhibition of SOD, with a parallel reduction of GPX activity that correlated with disease severity [283]. Notably, all these parameters were close to physiological values in the pre-symptomatic group of SCA3 patients [283].

Mutated ataxin 3 activity is connected with oxidative stress impairments in SCA3. Oxidative stress induces the nuclear translocation of ataxin 3 and this occurs both in normal and pathological conditions [284]. However, this acquires a particular importance in the pathologic context, as CAG-expanded repeats-containing proteins exert their toxic effects predominantly at nuclear level [285-289]. Because ROS production increases with age [290], the toxic effect could progressively worsen by time and increase neuronal death. Moreover, ataxin 3 has been found to interact with forkhead box class O 4 (FOXO4), a transcription factor implicated in the regulation of cell response to stress stimuli, including oxidative stress [291]. Under physiological conditions, ataxin 3 binding to FOXO4 is a necessary pre-requisite for SOD2 transcription. Although both normal and mutated ataxin 3 are able to interact with FOXO4, only the wild type protein can activate the FOXO4-dependent binding at SOD2 promoter. As a consequence, SOD2 expression is reduced in SCA3 cells, thus contributing to increase oxidative stress and cytotoxicity [292]. Several studies demonstrated reduced NRF2 levels in HEK293 and SH-SY5Y, after transfection with ataxin 3 mutant cDNA. The expression of NRF2 downstream targets were also reduced, thus determining a further increase of ROS [293,294]. Cell treatment with plant-derived antioxidant compounds were able to rescue these biochemical defects by triggering NRF2 activation and enhancing the expression of NQO1, GCL, GST, and SOD2 [293,294]. Importantly, the NRF2 activation, or its overexpression, reduced the aggregation of mutant ataxin 3 and the activation of the caspase3-dependent apoptotic pathway, while silencing the NRF2 expression led to increased ataxin 3 aggregates formation [294]. The administration of resveratrol and caffeic acid to mutant ataxin 3-expressing human SK-N-SH neuroblastoma cells and to a drosophila model of SCA3 enhanced the NRF2 activity, up-regulating the expression of NQO1, catalase, HO-1, GPX, SOD, and GR and causing a consistent reduction of total and mitochondrial ROS [295]. In parallel, the treatment was also able to induce the NRF2-mediated expression of autophagy-related proteins (i.e., p62), leading to decreased expression of mutant ataxin 3 and its aggregates (Figure 3), ultimately determining an extension of mutant flies life span [295].

The link between oxidative stress-induced damage and polyQ mutant protein aggregation was investigated also in SCA7, with similar results obtained in the studies described above. In PC12 cells, stably expressing a mutant ataxin 7 bearing $65 \mathrm{Q}$ residues, oxidative stress is increased, with a parallel reduction of GSH content and dysregulation of catalase, SOD1, and GST protein levels, 
due to the aberrant activation of the NADPH oxidase (NOX) complex [296]. These defects were ameliorated by the use of two antioxidants, N-acetyl cysteine (NAC) and vitamin E, both known to induce NRF2-dependent transcription [72,85]. Both compounds were able to reduce the level of mutant ataxin 7 aggregation [296]. Notably, by overexpressing SOD1 or $\operatorname{ROR} \alpha$, a transcriptional factor that activates the anti-oxidant gene transcription [297], a comparable reduction of mutant ataxin 7 aggregation was observed, further confirming the link between oxidative stress and pathologic polyQ protein [296]. In a mouse model of SCA17, the transcriptional dysregulation induced by CAG expanded TBP determines the downregulation of the heat shock protein beta1 (HSBP1) [298], a protein known to protect cells from oxidative stress in HD [299]. In addition, lymphoblastoid cells obtained from patients with SCA17 resulted highly susceptible to oxidative stress and to the ROS-induced cell death [300]. Proteomic analysis performed on SCA17 lymphoblastoid lines confirmed the involvement of the NRF2 signaling pathway in the disease, as evidenced by NQO1 and HO-1 different expression patterns in cells carrying mutation [301]. The treatment with two NRF2 inducers (resveratrol or genipin) [72,302] was able to rescue the antioxidant genes transcription defects and to low ROS generation [301]. Lastly, the implication of oxidative stress in the DRPLA pathogenic mechanism is poorly investigated to date, however, DNA and RNA oxidative by-products have been found in patients, particularly in a subset of cases showing progressive myoclonus epilepsy (PME) [303]. The SOD2 expression was reduced in 70\% of examined patients and this correlated with clinical symptoms of epilepsy [303].

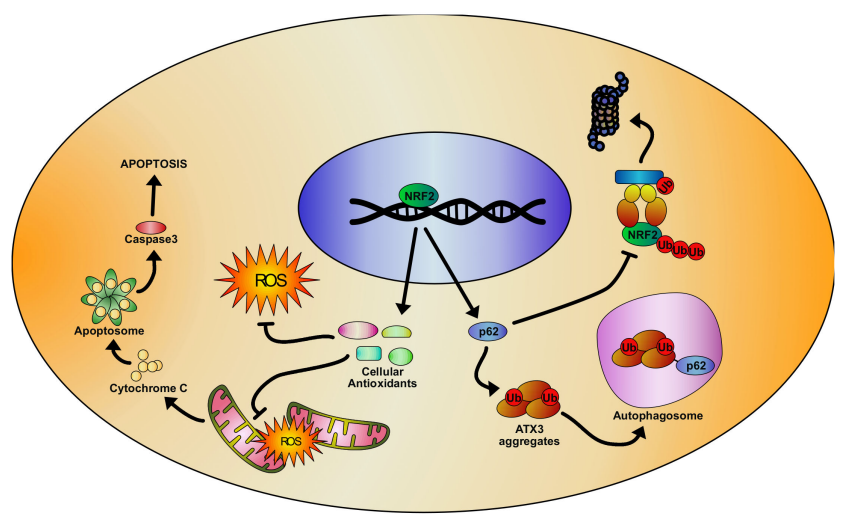

Figure 3. Representative model of the NRF2 signaling pathway activation in spinocerebellar ataxia 3 (SCA3), based on literature evidences. As a consequence of NRF2-mediated activation of the antioxidant response, reduction of cellular and mitochondrial ROS production is observed, thus inactivating the apoptotic pathway. In addition, NRF2 increases cellular levels of p62, which shuttles the mutant ataxin 3 aggregates to the autophagosomes, reducing their cellular concentration. At the same time, p62 interferes with the KEAP-1/NRF2 complexes, thus blocking the KEAP-1 mediated NRF2 degradation and sustaining its activity.

\section{Oxidative Stress in RNA Gain of Function Expansion Disease}

\subsection{Fragile X-Associated Tremor Ataxia Syndrome (FXTAS)}

While a number of CGG repetitions greater than 200 in the FMR1 gene determines FXS, CGG triplets ranging between 55-200 in the fragile $X$ locus, a condition known as pre-mutation state, gives rise to FXTAS [304,305]. FXTAS is a neurodegenerative disorder principally occurring in adult male carriers (50 years or more) and whose penetrance increases with age $[305,306]$. FXTAS clinical features include late onset and progressive cerebellar gait ataxia and intention tremor, with associated parkinsonism, cognitive deficits, and peripheral neuropathy [43,305-307]. Individuals developing FXTAS have normal or relatively low FMR1 protein levels, but increased FMR1 mRNA transcript [308], which accumulates in the nucleus of neurons and astrocytes in ubiquitin-positive inclusions [309,310]. Long CGG expansions in FMR1 mRNA are able to sequestrate numerous proteins that co-localize with the pathologic intranuclear inclusions in FXTAS animal models and patients [311-314]. FXTAS CGG 
expanded intranuclear inclusions are dynamic and form structures capable to trap a variety of proteins over time [47]. One of the first proteins to be sequestrated is the splicing factor SAM68 [47], a critical regulator of alternative splicing and polyadenylation in the nervous system [315-317]. Nevertheless, a recent work demonstrated that nearly 200 proteins can be found in FXTAS intranuclear inclusions, 36\% of them being RNA binding factors, with a strong enrichment of SUMO2, ubiquitin, and p62 proteins, indicating that aggregates are mostly composed of proteins tagged for degradation [314].

Oxidative stress is well known in FXTAS [318-321] and proteins belonging to redox response have been identified as SUMO2/3 substrates in patients, thus suggesting to be sequestrated in aggregates [314]. A number of mitochondrial dysfunctions has also been reported. A significant decline of oxidative phosphorylation (OXPHOS), increase of lipid peroxidation [318], oxidative biomarkers, and ROS [321] have been evidenced in fibroblasts and blood of FXTAS patients. Abnormal expression and function of mitochondrial proteins were further reported in patient's brain samples [320,322]. Because of this, oxidative stress has been proposed to participate to the FXTAS pathogenic formation of nuclear aggregates. By this model, a ROS-induced increase of oxidized proteins could exceed the UPS degradative capacity and lead to the accumulation of ubiquitin- and SUMO2/3-tagged proteins with mRNA molecules of FMRP1. In late stages, also the p62-mediated shuttling of aggregates towards autophagosomes would be abrogated, for the excessive enlargement of the inclusions, thus ultimately leading to the nuclear p62 trapping [314].

Some clues suggest the involvement of the NRF2 signalling pathway in this pathology. (i) Reduced expression of mnSOD, which is a NRF2 target gene, was attested in FXTAS [320]. (ii) Alterations of the mitochondrial network in patients [318] and impairments in their density and transport dynamics in mice carrying CGG premutation have been reported [323], both suggesting impairments in cytoskeletal proteins responsible for mitochondrial distribution and cell morphology [324]. These defects resemble the altered NRF2 trafficking observed in FA, where the increase of oxidative stress impairs cytoskeletal organization [325] by causing the mislocalizing of KEAP1-NRF2 complexes, normally bound to actin filaments [326], and leading to the failure of NRF2-mediated transcriptional activity [117]. (iii) As in FA, also in premutation carriers, FXN expression is low [322]. The reduced expression of the zinc transporter ZnT6 alters the zinc availability in FXTAS, impairing its incorporation, the mitochondrial processing peptidase (MPP), and the mitochondrial intermediate peptidase (MIP), two Zn-dependent proteases responsible for the maturation of mitochondrial proteins [327], including FXN [328,329]. The consequent increase of the premature form of FXN, in respect to the mature one, leads to defective iron metabolism and oxidative stress [322], and suggest that the similarities between FA and FXTAS could also be extended to NRF2 signalling pathway.

\subsection{Myotonic Dystrophy (DM)}

DM is an autosomal dominant disorder, which arises from 2 different mutations: DM1, determined by 50-1000 CUG triplets in the 3'UTR of DMPK gene [18,41] and DM2, caused by 75-11000 expansions of the tetranucleotide CCTG in the first intron of ZNF9. [18,42]. DM1 and DM2 are multisystemic diseases sharing a common symptomatology characterized by myotonia, muscular dystrophy, cardiac defects, cataracts [330], and neurological manifestations [331,332]. Unlike DM1, DM2 does not show congenital forms [333]. DM shows a marked somatic instability of repeat expansions that, in DM1, are reported to increase of about 50-80 repeats per year and, in DM2, appear to be even more pronounced [330,334,335]. Depending on the repeat length, the severity of DM1 and the onset of the pathology range from "mild" manifestation (baldness and cataracts) to a "classic" or "juvenile" form, with worse symptoms [19]. On the contrary, although the same clinical heterogeneity is observed in DM2, the pathologic onset and disease severity do not seem to depend on the size of expansions in this disorder [336]. Clinical anticipation, prominent in DM1 [337], appears mildly in DM2 [338].

Different hypotheses have been proposed to explain the pathogenic mechanism in DM. Early studies suggested that the pathological defects observed in DM1 could be determined by the decrease of DMPK expression, mediated by CUG expansions [339] and/or by the trans-acting effect of the expanded 
mRNA, able to reduce the processing of WT DMPK mRNA [340]. Clinical similarities led to support a common pathogenic mechanism for DM1 and DM2 and, to date, an RNA toxic gain of function is the most credited. In particular, both CUG triplet containing DMPK mRNA and spliced ZNF9 intron1 containing long CCTG sequences are able to sequestrate in the nucleus the splicing factors MBNL1 and 2 [341,342] and, at the same time, to raise the RNA binding activity of CUG-binding protein 1 (CUG-BP1 or CELF1) [330,343]. This changes the cellular alternative splicing output, determining the defects observed in the disease [46,344].

Many of the clinical features showed in DM, including myotonia, progressive muscle weakness, cataracts, frontal alopecia, and cognitive decline, suggest an increased susceptibility to oxidative stress in this pathology, as observed in premature and accelerated aging [345]. While in DM2, oxidative stress is still poor investigated, a pathogenic involvement of ROS has been evidenced in DM1. Increased sensitivity to oxidative stress and strong activation of the pro-apoptotic p38 and JNKs pathways have been reported in the $\mathrm{C} 2 \mathrm{C} 12$ cell line transfected with human mutant MDPK containing a variable number of CTG repeats [346]. On the contrary, in cells having only 5 CTG repeats, ERKs were preferentially activated [347]. Moreover, studies performed in DM patients have demonstrated an increase of lipid peroxidation and ROS levels, with a parallel decrease of the antioxidant $\operatorname{CoQ}_{10}$ content [348]. Increased oxidative stress and ROS-induced inflammation are known to produce cognitive dysfunctions [349,350] and depressive behaviours [351,352], conditions observed in the MBNL2 KO mouse model of DM1 [353]. In these mice, the chronic administration of methylphenidate (MPH) was able to partially rescue the cognitive defects and depressive-like behaviours, and to reduce the reactive microglia and pro-inflammatory cytokine IL-1 $\beta$ levels [353]. The treatment with MPH was shown to increase NRF2 gene expression in the hippocampus of MBNL2 KO mice and the brain-derived neurotrophic factor (BDNF) levels, which regulates NRF2 nuclear translocation by means of an ERK/PI3K-dependent activation [354]. These findings suggest that the rescue of behavioural defects in MBNL2 KO mice may depend on NRF2-mediated reduction of oxidative stress and inflammation. In line with this, it is important to note that in NRF2 KO mice, an increase of the serum level of pro-inflammatory cytokines and a decrease of the BDNF expression have been reported in association to a depressive-like phenotype [355]. In the same way, NRF2 activation is able to reduce depression and serum content of pro-inflammatory markers induced by lipopolysaccharide (LPS) injections in mice [356]. Cognitive defects [331,332] and depression [357], together with serum increased concentration of the pro-inflammatory IL-6 [358] have been found in DM1 patients, thus the pharmacological NRF2 induction could be very promising in this disease (Figure 4).

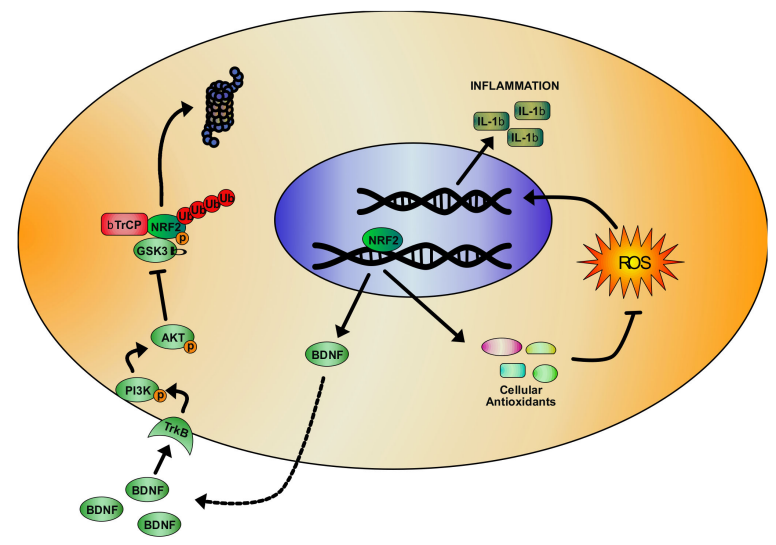

Figure 4. Representative model of the NRF2 signaling pathway activation in myotonic dystrophy 1 (DM1), based on literature evidences. Brain-derived neurotrophic factor (BDNF) activation of PI3K/AKT pathway determines the inhibitory phosphorylation of GSK3 $\beta$ by blocking NRF2/KEAP-1-indipendent degradation. As BDNF is a NRF2 target, this can start a positive feedback contributing to NRF2 activation. At the same time, the transcription of NRF2 antioxidant target genes reduces oxidative stress in DM1 cells and the pro-inflammatory cytokine IL-1 $\beta$ levels. 


\section{Conclusions}

Around the first years of the 1990s, the discovery of a new type of unstable mutation, the expansion of DNA microsatellite repeats, was found as the underlying cause of FXS, DM, and SBMA [359], helping to understand the molecular basis of the clinical anticipation concept in heritable diseases and allowing the definition of a new class of disorders, characterized by the earlier onset and severity in succeeding generations. Since then, this class has expanded, making the current subdivision, which accounts for the general pathogenic mechanism (i.e., loss/gain of function of protein or mRNA), necessary. As, to date, DNA expansions are known to cause more than 30 disorders (16), it is somehow surprising that oxidative stress is involved in a major part of such a vast group of pathologies. At the same time, mounting evidence points at ROS imbalance as a common thread in neurodegeneration and a plethora of neurodegenerative conditions share oxidative-related defects $[48,49]$. Cellular pathways in charge of regulating the oxidative stress defenses are often deregulated in DNA expansion disorders, providing an inadequate response to ROS overload. In line with this, the NRF2-ARE axis has been found to be defective in most of the pathologies we reviewed here and, in some of these, beneficial effects have been observed by modulating NRF2 signaling (Table 1). Therapeutic interventions aimed at re-establishing the NRF2 pathway can be very promising to ameliorate the patient's condition by rescuing oxidative stress-induced defects. Notably, NRF2 induction has been demonstrated to partially recover the primary defects in FA $[85,135-137]$ and in SCA3, where it mediates the reduction of ataxin 3 aggregates $[294,295]$, thus paving the way for NRF2-targeted therapies.

Table 1. Table summarizing findings on antioxidant drugs/NRF2-activating compounds and their main effects in DNA repeat expansion disorders.

\begin{tabular}{|c|c|c|c|c|}
\hline Disease & Compound & Model & Effect of Treatment & Ref. \\
\hline \multirow[t]{4}{*}{ FA } & $\begin{array}{l}\text { SFN, DMF, NAC, } \\
\text { EPI-743, RTA408, } \\
\text { Idebenone }\end{array}$ & $\begin{array}{l}\text { FA patients' } \\
\text { fibroblasts }\end{array}$ & $\begin{array}{l}\text { Increase of GSH content; enhancement of } F X N \text {, } \\
\text { NRF2 and down-stream genes mRNA. }\end{array}$ & [111] \\
\hline & SFN, DMF & $\begin{array}{l}\text { shFXN NSC34 } \\
\text { motor neurons }\end{array}$ & $\begin{array}{l}\text { Rebalance of GSH/GSSG ratio; increase of FXN, } \\
\text { NRF2 and down-stream genes expression. }\end{array}$ & [124] \\
\hline & Idebenone & Patients & Reduction of cardiac hypertrophy. & [128] \\
\hline & EPI-743 & Patients & Improvement of neurological functions. & [132] \\
\hline \multirow[t]{2}{*}{ SBMA } & ASC-J9 & $\begin{array}{l}\text { AR-112Q PC12 } \\
\text { cells; AR-97Q mice }\end{array}$ & $\begin{array}{l}\text { Reduction of AR aggregates; rescue of motor } \\
\text { defects and muscular atrophy; increase of VEGF } \\
\text { expression. }\end{array}$ & [203] \\
\hline & ASC-J17 & $\begin{array}{l}\text { SBMA patients' } \\
\text { fibroblasts; AR97Q } \\
\text { mouse; AR52Q } \\
\text { drosophila }\end{array}$ & $\begin{array}{l}\text { Increase of NRF2 down-stream genes; suppression } \\
\text { of polyQ toxicity in mutant flies; amelioration of } \\
\text { mutant mice phenotype and decrease of mutant } \\
\text { AR accumulation. }\end{array}$ & [204] \\
\hline \multirow[t]{3}{*}{ HD } & SFN & mHtt-94Q Hek293 & $\begin{array}{l}\text { Increase of mHtt degradation and reduction of } \\
\text { mHtt-induced toxicity. }\end{array}$ & [232] \\
\hline & MIND4-17 & $\begin{array}{l}\text { HD patients' } \\
\text { primary monocytes }\end{array}$ & Reduction of inflammatory cytokines expression. & [233] \\
\hline & DMF & $\begin{array}{l}\mathrm{R} 6 / 2 \text { and } \mathrm{YAC} 128 \\
\text { mice }\end{array}$ & $\begin{array}{l}\text { Increased survival and motor functions; } \\
\text { preservation of striatal neurons morphology; } \\
\text { increase of NRF2 expression. }\end{array}$ & [236] \\
\hline SCA1 & MitoQ & Sca1 154Q/2Q mice & $\begin{array}{l}\text { Improvement of motor coordination defects; } \\
\text { reduction of mitochondrial morphological } \\
\text { abnormalities and ETC activity defects. }\end{array}$ & [262] \\
\hline \multirow[t]{2}{*}{ SCA3 } & $\begin{array}{l}\text { Glycyrrhiza inflata } \\
\text { extract, AMGZ, } \\
\text { Licochalcone A }\end{array}$ & $\begin{array}{l}\text { ATXN3/Q75-GFP } \\
\text { Hek293 and } \\
\text { SH-SY5Y cells }\end{array}$ & $\begin{array}{l}\text { Decrease of Ataxin } 3 \text { aggregates; up-regulation of } \\
\text { NRF2 and down-stream genes; reduction of GSSG } \\
\text { and ROS levels. }\end{array}$ & [282] \\
\hline & $\begin{array}{l}\text { Gardenia jasminoides } \\
\text { extract, genipin, } \\
\text { geniposide, crocin }\end{array}$ & $\begin{array}{l}\text { ATXN3/Q75-GFP } \\
\text { Hek293 and } \\
\text { SH-SY5Y cells }\end{array}$ & $\begin{array}{l}\text { Reduction of Ataxin } 3 \text { aggregates and Caspase } 3 \\
\text { activity; increase of NRF2 and its target genes; } \\
\text { decrease of ROS concentration. }\end{array}$ & [283] \\
\hline SCA17 & $\begin{array}{l}\text { Resveratrol, } \\
\text { genipin }\end{array}$ & $\begin{array}{l}\text { SCA17 } \\
\text { lynfoblastoid cells }\end{array}$ & $\begin{array}{l}\text { Increase of NRF2 antioxidant target genes and cell } \\
\text { viability; decrease of ROS. }\end{array}$ & [290] \\
\hline DM1 & $\mathrm{MPH}$ & Mbnl2 KO mice. & $\begin{array}{l}\text { Increase of NRF2 and BDNF expression; rescue of } \\
\text { behavioral deficits; decrease of inflammation. }\end{array}$ & [344] \\
\hline
\end{tabular}




\section{Author Contributions}

Conceptualization: P.L.R, F.P.; writing of the Huntington's disease and Friedreich's ataxia sections: S.P.; writing \& editing: P.L.R., E.S.B., F.P.; figures: P.L.R. All authors have read and agreed to the published version of the manuscript.

Funding: This work was supported by Ricerca Corrente of the Italian Ministry of Health. Our Centre belongs to the ERN RND network.

Conflicts of Interest: The authors declare no conflict of interest.

\section{References}

1. Gur-Arie, R.; Cohen, C.J.; Eitan, Y.; Shelef, L.; Hallerman, E.M.; Kashi, Y. Simple sequence repeats in Escherichia coli: Abundance, distribution, composition, and polymorphism. Genome Res. 2000, 10, 62-71. [CrossRef] [PubMed]

2. Hamada, H.; Petrino, M.G.; Kakunaga, T. A novel repeated element with Z-DNA-forming potential is widely found in evolutionarily diverse eukaryotic genomes. Proc. Natl. Acad. Sci. USA 1982, 79, 6465-6469. [CrossRef] [PubMed]

3. Lander, E.S.; Linton, L.M.; Birren, B.; Nusbaum, C.; Zody, M.C.; Baldwin, J.; Devon, K.; Dewar, K.; Doyle, M.; FitzHugh, W.; et al. Initial sequencing and analysis of the human genome. Nature 2001, 409, 860-921. [CrossRef] [PubMed]

4. Beckman, J.S.; Weber, J.L. Survey of human and rat microsatellites. Genomics 1992, 12, 627-631. [CrossRef]

5. Toth, G.; Gaspari, Z.; Jurka, J. Microsatellites in different eukaryotic genomes: Survey and analysis. Genome Res. 2000, 10, 967-981. [CrossRef]

6. Metzgar, D.; Bytof, J.; Wills, C. Selection against frameshift mutations limits microsatellite expansion in coding DNA. Genome Res. 2000, 10, 72-80.

7. Bagshaw, A.T.M. Functional Mechanisms of Microsatellite DNA in Eukaryotic Genomes. Genome Biol. Evol. 2017, 9, 2428-2443. [CrossRef]

8. Hui, J.; Hung, L.H.; Heiner, M.; Schreiner, S.; Neumuller, N.; Reither, G.; Haas, S.A.; Bindereif, A. Intronic CA-repeat and CA-rich elements: A new class of regulators of mammalian alternative splicing. Embo J. 2005, 24, 1988-1998. [CrossRef]

9. Tseng, S.H.; Cheng, C.Y.; Huang, M.Z.; Chung, M.Y.; Su, T.S. Modulation of formation of the $3^{\prime}$-end of the human argininosuccinate synthetase mRNA by GT-repeat polymorphism. Int. J. Biochem. Mol. Biol. 2013, 4, 179-190.

10. Kramer, M.; Sponholz, C.; Slaba, M.; Wissuwa, B.; Claus, R.A.; Menzel, U.; Huse, K.; Platzer, M.; Bauer, M. Alternative $5^{\prime}$ untranslated regions are involved in expression regulation of human heme oxygenase-1. PLoS ONE 2013, 8, e77224. [CrossRef]

11. Liu, H.; Mulholland, N.; Fu, H.; Zhao, K. Cooperative activity of BRG1 and Z-DNA formation in chromatin remodeling. Mol. Cell. Biol. 2006, 26, 2550-2559. [CrossRef] [PubMed]

12. Quilez, J.; Guilmatre, A.; Garg, P.; Highnam, G.; Gymrek, M.; Erlich, Y.; Joshi, R.S.; Mittelman, D.; Sharp, A.J. Polymorphic tandem repeats within gene promoters act as modifiers of gene expression and DNA methylation in humans. Nucleic Acids Res. 2016, 44, 3750-3762. [CrossRef] [PubMed]

13. Ellegren, H. Microsatellite mutations in the germline: Implications for evolutionary inference. Trends Genet. 2000, 16, 551-558. [CrossRef]

14. Chistiakov, D.A.; Hellemans, B.; Volckaert, F.A.M. Microsatellites and their genomic distribution, evolution, function and applications: A review with special reference to fish genetics. Aquaculture 2006, 255, 1-29. [CrossRef]

15. Weissenbach, J. Microsatellite polymorphisms and the genetic linkage map of the human genome. Curr. Opin. Genet. Dev. 1993, 3, 414-417. [CrossRef]

16. López Castel, A.; Cleary, J.D.; Pearson, C.E. Repeat instability as the basis for human diseases and as a potential target for therapy. Nat. Rev. Mol. Cell Biol. 2010, 11, 165-170. [CrossRef]

17. Pearson, C.E.; Nichol Edamura, K.; Cleary, J.D. Repeat instability: Mechanisms of dynamic mutations. Nat. Rev. Genet. 2005, 6, 729-742. [CrossRef] 
18. Gatchel, J.R.; Zoghbi, H.Y. Diseases of unstable repeat expansion: Mechanisms and common principles. Nat. Rev. Genet. 2005, 6, 743-755. [CrossRef]

19. Paulson, H. Repeat expansion diseases. Handb. Clin. Neurol. 2018, 147, 105-123. [CrossRef]

20. McInnis, M.G. Anticipation: An old idea in new genes. Am. J. Hum. Genet. 1996, 59, 973-979.

21. Van Mossevelde, S.; van der Zee, J.; Gijselinck, I.; Sleegers, K.; De Bleecker, J.; Sieben, A.; Vandenberghe, R.; Van Langenhove, T.; Baets, J.; Deryck, O.; et al. Clinical Evidence of Disease Anticipation in Families Segregating a C9orf72 Repeat Expansion. JAMA Neurol. 2017, 74, 445-452. [CrossRef] [PubMed]

22. Paulson, H.L.; Fischbeck, K.H. Trinucleotide repeats in neurogenetic disorders. Annu. Rev. Neurosci. 1996, 19, 79-107. [CrossRef]

23. Reetz, K.; Dogan, I.; Costa, A.S.; Dafotakis, M.; Fedosov, K.; Giunti, P.; Parkinson, M.H.; Sweeney, M.G.; Mariotti, C.; Panzeri, M.; et al. Biological and clinical characteristics of the European Friedreich's Ataxia Consortium for Translational Studies (EFACTS) cohort: A cross-sectional analysis of baseline data. Lancet Neurol. 2015, 14, 174-182. [CrossRef]

24. Cook, A.; Giunti, P. Friedreich's ataxia: Clinical features, pathogenesis and management. Br. Med Bull. 2017, 124, 19-30. [CrossRef]

25. Andrew, S.E.; Goldberg, Y.P.; Kremer, B.; Telenius, H.; Theilmann, J.; Adam, S.; Starr, E.; Squitieri, F.; Lin, B.; Kalchman, M.A.; et al. The relationship between trinucleotide (CAG) repeat length and clinical features of Huntington's disease. Nat. Genet. 1993, 4, 398-403. [CrossRef] [PubMed]

26. Figueroa, K.P.; Coon, H.; Santos, N.; Velazquez, L.; Mederos, L.A.; Pulst, S.-M. Genetic analysis of age at onset variation in spinocerebellar ataxia type 2. Neurol. Genet. 2017, 3, e155. [CrossRef]

27. Igarashi, S.; Tanno, Y.; Onodera, O.; Yamazaki, M.; Sato, S.; Ishikawa, A.; Miyatani, N.; Nagashima, M.; Ishikawa, Y.; Sahashi, K.; et al. Strong correlation between the number of CAG repeats in androgen receptor genes and the clinical onset of features of spinal and bulbar muscular atrophy. Neurology 1992, 42, 2300-2302. [CrossRef]

28. Savić, D.; Rakocvic-Stojanovic, V.; Keckarevic, D.; Culjkovic, B.; Stojkovic, O.; Mladenovic, J.; Todorovic, S.; Apostolski, S.; Romac, S. 250 CTG repeats in DMPK is a threshold for correlation of expansion size and age at onset of juvenile-adult DM1. Hum. Mutat. 2002, 19, 131-139. [CrossRef]

29. Leehey, M.A.; Berry-Kravis, E.; Goetz, C.G.; Zhang, L.; Hall, D.A.; Li, L.; Rice, C.D.; Lara, R.; Cogswell, J.; Reynolds, A.; et al. FMR1 CGG repeat length predicts motor dysfunction in premutation carriers. Neurology 2008, 70, 1397-1402. [CrossRef]

30. Delatycki, M.B.; Paris, D.B.; Gardner, R.J.; Nicholson, G.A.; Nassif, N.; Storey, E.; MacMillan, J.C.; Collins, V.; Williamson, R.; Forrest, S.M. Clinical and genetic study of Friedreich ataxia in an Australian population. Am. J. Med. Genet. 1999, 87, 168-174. [CrossRef]

31. Cossée, M.; Dürr, A.; Schmitt, M.; Dahl, N.; Trouillas, P.; Allinson, P.; Kostrzewa, M.; Nivelon-Chevallier, A.; Gustavson, K.H.; Kohlschütter, A.; et al. Friedreich's ataxia: Point mutations and clinical presentation of compound heterozygotes. Ann. Neurol. 1999, 45, 200-206. [CrossRef]

32. De Michele, G.; Perrone, F.; Filla, A.; Mirante, E.; Giordano, M.; De Placido, S.; Campanella, G. Age of onset, sex, and cardiomyopathy as predictors of disability and survival in Friedreich's disease: A retrospective study on 119 patients. Neurology 1996, 47, 1260-1264. [CrossRef] [PubMed]

33. Cnop, M.; Mulder, H.; Igoillo-Esteve, M. Diabetes in Friedreich ataxia. J. Neurochem. 2013, 126 (Suppl. 1), 94-102. [CrossRef]

34. Arsenault, M.E.; Prévost, C.; Lescault, A.; Laberge, C.; Puymirat, J.; Mathieu, J. Clinical characteristics of myotonic dystrophy type 1 patients with small CTG expansions. Neurology 2006, 66, 1248-1250. [CrossRef] [PubMed]

35. Feng, Y.; Zhang, F.; Lokey, L.K.; Chastain, J.L.; Lakkis, L.; Eberhart, D.; Warren, S.T. Translational suppression by trinucleotide repeat expansion at FMR1. Science 1995, 268, 731-734. [CrossRef] [PubMed]

36. Campuzano, V.; Montermini, L.; Molto, M.D.; Pianese, L.; Cossee, M.; Cavalcanti, F.; Monros, E.; Rodius, F.; Duclos, F.; Monticelli, A.; et al. Friedreich's ataxia: Autosomal recessive disease caused by an intronic GAA triplet repeat expansion. Science 1996, 271, 1423-1427. [CrossRef] [PubMed]

37. Zoghbi, H.Y.; Orr, H.T. Glutamine repeats and neurodegeneration. Annu. Rev. Neurosci. 2000, 23, $217-247$. [CrossRef] [PubMed] 
38. Nucifora, F.C., Jr.; Sasaki, M.; Peters, M.F.; Huang, H.; Cooper, J.K.; Yamada, M.; Takahashi, H.; Tsuji, S.; Troncoso, J.; Dawson, V.L.; et al. Interference by huntingtin and atrophin-1 with cbp-mediated transcription leading to cellular toxicity. Science 2001, 291, 2423-2428. [CrossRef]

39. Dunah, A.W.; Jeong, H.; Griffin, A.; Kim, Y.-M.; Standaert, D.G.; Hersch, S.M.; Mouradian, M.M.; Young, A.B.; Tanese, N.; Krainc, D. Sp1 and TAFII130 transcriptional activity disrupted in early Huntington's disease. Science 2002, 296, 2238-2243. [CrossRef]

40. Ciechanover, A.; Brundin, P. The ubiquitin proteasome system in neurodegenerative diseases: Sometimes the chicken, sometimes the egg. Neuron 2003, 40,427-446. [CrossRef]

41. Mahadevan, M.; Tsilfidis, C.; Sabourin, L.; Shutler, G.; Amemiya, C.; Jansen, G.; Neville, C.; Narang, M.; Barceló, J.; O'Hoy, K.; et al. Myotonic dystrophy mutation: An unstable CTG repeat in the 3' untranslated region of the gene. Science 1992, 255, 1253-1255. [CrossRef] [PubMed]

42. Ranum, L.P.; Rasmussen, P.F.; Benzow, K.A.; Koob, M.D.; Day, J.W. Genetic mapping of a second myotonic dystrophy locus. Nat. Genet. 1998, 19, 196-198. [CrossRef] [PubMed]

43. Jacquemont, S.; Hagerman, R.J.; Leehey, M.; Grigsby, J.; Zhang, L.; Brunberg, J.A.; Greco, C.; Des Portes, V.; Jardini, T.; Levine, R.; et al. Fragile X premutation tremor/ataxia syndrome: Molecular, clinical, and neuroimaging correlates. Am. J. Hum. Genet. 2003, 72, 869-878. [CrossRef] [PubMed]

44. Echeverria, G.V.; Cooper, T.A. Muscleblind-like 1 activates insulin receptor exon 11 inclusion by enhancing U2AF65 binding and splicing of the upstream intron. Nucleic Acids Res. 2014, 42, 1893-1903. [CrossRef]

45. Savkur, R.S.; Philips, A.V.; Cooper, T.A. Aberrant regulation of insulin receptor alternative splicing is associated with insulin resistance in myotonic dystrophy. Nat. Genet. 2001, 29, 40-47. [CrossRef]

46. Mankodi, A.; Takahashi, M.P.; Jiang, H.; Beck, C.L.; Bowers, W.J.; Moxley, R.T.; Cannon, S.C.; Thornton, C.A. Expanded CUG repeats trigger aberrant splicing of $\mathrm{ClC}-1$ chloride channel pre-mRNA and hyperexcitability of skeletal muscle in myotonic dystrophy. Mol. Cell 2002, 10, 35-44. [CrossRef]

47. Sellier, C.; Rau, F.; Liu, Y.; Tassone, F.; Hukema, R.K.; Gattoni, R.; Schneider, A.; Richard, S.; Willemsen, R.; Elliott, D.J.; et al. Sam68 sequestration and partial loss of function are associated with splicing alterations in FXTAS patients. EMBO J. 2010, 29, 1248-1261. [CrossRef]

48. Kim, G.H.; Kim, J.E.; Rhie, S.J.; Yoon, S. The Role of Oxidative Stress in Neurodegenerative Diseases. Exp. Neurobiol. 2015, 24, 325-340. [CrossRef]

49. Liu, Z.; Zhou, T.; Ziegler, A.C.; Dimitrion, P.; Zuo, L. Oxidative Stress in Neurodegenerative Diseases: From Molecular Mechanisms to Clinical Applications. Oxid. Med. Cell. Longev. 2017, 2017, 2525967. [CrossRef]

50. Ryter, S.W.; Kim, H.P.; Hoetzel, A.; Park, J.W.; Nakahira, K.; Wang, X.; Choi, A.M. Mechanisms of cell death in oxidative stress. Antioxid. Redox Signal. 2007, 9, 49-89. [CrossRef]

51. Ghosh, N.; Das, A.; Chaffee, S.; Roy, S.; Sen, C.K. Chapter 4-Reactive Oxygen Species, Oxidative Damage and Cell Death. In Immunity and Inflammation in Health and Disease; Chatterjee, S., Jungraithmayr, W., Bagchi, D., Eds.; Academic Press: Cambridge, MA, USA, 2018; pp. 45-55. [CrossRef]

52. Birben, E.; Sahiner, U.M.; Sackesen, C.; Erzurum, S.; Kalayci, O. Oxidative stress and antioxidant defense. World Allergy Organ J. 2012, 5, 9-19. [CrossRef] [PubMed]

53. Thanan, R.; Oikawa, S.; Hiraku, Y.; Ohnishi, S.; Ma, N.; Pinlaor, S.; Yongvanit, P.; Kawanishi, S.; Murata, M. Oxidative stress and its significant roles in neurodegenerative diseases and cancer. Int. J. Mol. Sci. 2014, 16, 193-217. [CrossRef] [PubMed]

54. Venditti, P.; Di Stefano, L.; Di Meo, S. Mitochondrial metabolism of reactive oxygen species. Mitochondrion 2013, 13, 71-82. [CrossRef]

55. Rahal, A.; Kumar, A.; Singh, V.; Yadav, B.; Tiwari, R.; Chakraborty, S.; Dhama, K. Oxidative stress, prooxidants, and antioxidants: The interplay. Biomed. Res. Int. 2014, 2014, 761264. [CrossRef] [PubMed]

56. Ray, P.D.; Huang, B.W.; Tsuji, Y. Reactive oxygen species (ROS) homeostasis and redox regulation in cellular signaling. Cell Signal 2012, 24, 981-990. [CrossRef]

57. Schieber, M.; Chandel, N.S. ROS function in redox signaling and oxidative stress. Curr. Biol. 2014, 24, R453-R462. [CrossRef] [PubMed]

58. D'Autreaux, B.; Toledano, M.B. ROS as signalling molecules: Mechanisms that generate specificity in ROS homeostasis. Nat. Rev. Mol. Cell. Biol. 2007, 8, 813-824. [CrossRef]

59. Younus, H. Therapeutic potentials of superoxide dismutase. Int. J. Health Sci. 2018, 12, 88-93.

60. Nandi, A.; Yan, L.-J.; Jana, C.K.; Das, N. Role of Catalase in Oxidative Stress- and Age-Associated Degenerative Diseases. Oxid. Med. Cell. Longev. 2019, 2019, 9613090. [CrossRef] 
61. Brigelius-Flohé, R.; Maiorino, M. Glutathione peroxidases. Biochim. Biophys. Acta 2013, 1830, 3289-3303. [CrossRef]

62. Mirończuk-Chodakowska, I.; Witkowska, A.M.; Zujko, M.E. Endogenous non-enzymatic antioxidants in the human body. Adv. Med. Sci. 2018, 63, 68-78. [CrossRef] [PubMed]

63. Haenen, G.R.M.M.; Bast, A. Glutathione revisited: A better scavenger than previously thought. Front. Pharmacol. 2014, 5, 260. [CrossRef] [PubMed]

64. Aquilano, K.; Baldelli, S.; Ciriolo, M.R. Glutathione: New roles in redox signaling for an old antioxidant. Front. Pharmacol. 2014, 5, 196. [CrossRef] [PubMed]

65. Brigelius-Flohé, R. Tissue-specific functions of individual glutathione peroxidases. Free Radic. Biol. Med. 1999, 27, 951-965. [CrossRef]

66. Sheehan, D.; Meade, G.; Foley, V.M.; Dowd, C.A. Structure, function and evolution of glutathione transferases: Implications for classification of non-mammalian members of an ancient enzyme superfamily. Biochem. J. 2001, 360, 1-16. [CrossRef]

67. Forman, H.J.; Zhang, H.; Rinna, A. Glutathione: Overview of its protective roles, measurement, and biosynthesis. Mol. Asp. Med. 2009, 30,1-12. [CrossRef]

68. Njålsson, R.; Norgren, S. Physiological and pathological aspects of GSH metabolism. Acta Paediatr. 2005, 94, 132-137. [CrossRef]

69. Kasai, S.; Shimizu, S.; Tatara, Y.; Mimura, J.; Itoh, K. Regulation of Nrf2 by Mitochondrial Reactive Oxygen Species in Physiology and Pathology. Biomolecules 2020, 10, 320. [CrossRef]

70. Ma, Q. Role of nrf2 in oxidative stress and toxicity. Annu. Rev. Pharmacol. Toxicol. 2013, 53, 401-426. [CrossRef]

71. Shaw, P.; Chattopadhyay, A. Nrf2-ARE signaling in cellular protection: Mechanism of action and the regulatory mechanisms. J. Cell. Physiol. 2019, 235, 3119-3130. [CrossRef]

72. La Rosa, P.; Bertini, E.S.; Piemonte, F. The NRF2 Signaling Network Defines Clinical Biomarkers and Therapeutic Opportunity in Friedreich's Ataxia. Int. J. Mol. Sci. 2020, 21, 916. [CrossRef] [PubMed]

73. Moi, P.; Chan, K.; Asunis, I.; Cao, A.; Kan, Y.W. Isolation of NF-E2-related factor 2 (Nrf2), a NF-E2-like basic leucine zipper transcriptional activator that binds to the tandem NF-E2/AP1 repeat of the beta-globin locus control region. Proc. Natl. Acad. Sci. USA 1994, 91, 9926-9930. [CrossRef]

74. Amoutzias, G.D.; Robertson, D.L.; Van de Peer, Y.; Oliver, S.G. Choose your partners: Dimerization in eukaryotic transcription factors. Trends Biochem. Sci. 2008, 33, 220-229. [CrossRef] [PubMed]

75. Igarashi, K.; Kataoka, K.; Itoh, K.; Hayashi, N.; Nishizawa, M.; Yamamoto, M. Regulation of transcription by dimerization of erythroid factor NF-E2 p45 with small Maf proteins. Nature 1994, 367, 568-572. [CrossRef] [PubMed]

76. Itoh, K.; Chiba, T.; Takahashi, S.; Ishii, T.; Igarashi, K.; Katoh, Y.; Oyake, T.; Hayashi, N.; Satoh, K.; Hatayama, I.; et al. An Nrf2/small Maf heterodimer mediates the induction of phase II detoxifying enzyme genes through antioxidant response elements. Biochem. Biophys. Res. Commun. 1997, 236, 313-322. [CrossRef]

77. Wasserman, W.W.; Fahl, W.E. Functional antioxidant responsive elements. Proc. Natl. Acad. Sci. USA 1997, 94, 5361-5366. [CrossRef]

78. Cuadrado, A.; Rojo, A.I.; Wells, G.; Hayes, J.D.; Cousin, S.P.; Rumsey, W.L.; Attucks, O.C.; Franklin, S.; Levonen, A.L.; Kensler, T.W.; et al. Therapeutic targeting of the NRF2 and KEAP1 partnership in chronic diseases. Nat. Rev. Drug Discov. 2019, 18, 295-317. [CrossRef]

79. Corenblum, M.J.; Ray, S.; Remley, Q.W.; Long, M.; Harder, B.; Zhang, D.D.; Barnes, C.A.; Madhavan, L. Reduced Nrf2 expression mediates the decline in neural stem cell function during a critical middle-age period. Aging Cell 2016, 15, 725-736. [CrossRef] [PubMed]

80. Dodson, M.; de la Vega, M.R.; Cholanians, A.B.; Schmidlin, C.J.; Chapman, E.; Zhang, D.D. Modulating NRF2 in Disease: Timing Is Everything. Annu. Rev. Pharmacol. Toxicol. 2019, 59, 555-575. [CrossRef]

81. La Rosa, P.; Russo, M.; D’Amico, J.; Petrillo, S.; Aquilano, K.; Lettieri-Barbato, D.; Turchi, R.; Bertini, E.S.; Piemonte, F. Nrf2 Induction Re-establishes a Proper Neuronal Differentiation Program in Friedreich's Ataxia Neural Stem Cells. Front. Cell. Neurosci. 2019, 13, 356. [CrossRef]

82. Robledinos-Anton, N.; Rojo, A.I.; Ferreiro, E.; Nunez, A.; Krause, K.H.; Jaquet, V.; Cuadrado, A. Transcription factor NRF2 controls the fate of neural stem cells in the subgranular zone of the hippocampus. Redox Biol. 2017, 13, 393-401. [CrossRef] 
83. Turchi, R.; Tortolici, F.; Guidobaldi, G.; Iacovelli, F.; Falconi, M.; Rufini, S.; Faraonio, R.; Casagrande, V.; Federici, M.; De Angelis, L.; et al. Frataxin deficiency induces lipid accumulation and affects thermogenesis in brown adipose tissue. Cell Death Dis. 2020, 11, 51. [CrossRef] [PubMed]

84. Kasai, S.; Yamazaki, H.; Tanji, K.; Engler, M.J.; Matsumiya, T.; Itoh, K. Role of the ISR-ATF4 pathway and its cross talk with Nrf2 in mitochondrial quality control. J. Clin. Biochem. Nutr. 2019, 64, 1-12. [CrossRef]

85. Petrillo, S.; D'Amico, J.; La Rosa, P.; Bertini, E.S.; Piemonte, F. Targeting NRF2 for the Treatment of Friedreich's Ataxia: A Comparison among Drugs. Int. J. Mol. Sci. 2019, 20, 5211. [CrossRef] [PubMed]

86. Cuadrado, A. Structural and functional characterization of Nrf2 degradation by glycogen synthase kinase 3/beta-TrCP. Free Radic. Biol. Med. 2015, 88, 147-157. [CrossRef] [PubMed]

87. Kobayashi, A.; Kang, M.I.; Okawa, H.; Ohtsuji, M.; Zenke, Y.; Chiba, T.; Igarashi, K.; Yamamoto, M. Oxidative stress sensor Keap1 functions as an adaptor for Cul3-based E3 ligase to regulate proteasomal degradation of Nrf2. Mol. Cell. Biol. 2004, 24, 7130-7139. [CrossRef]

88. Yamamoto, M.; Kensler, T.W.; Motohashi, H. The KEAP1-NRF2 System: A Thiol-Based Sensor-Effector Apparatus for Maintaining Redox Homeostasis. Physiol. Rev. 2018, 98, 1169-1203. [CrossRef]

89. Rada, P.; Rojo, A.I.; Chowdhry, S.; McMahon, M.; Hayes, J.D.; Cuadrado, A. SCF/beta-TrCP promotes glycogen synthase kinase 3-dependent degradation of the Nrf2 transcription factor in a Keap1-independent manner. Mol. Cell. Biol. 2011, 31, 1121-1133. [CrossRef]

90. Wu, S.; Lu, H.; Bai, Y. Nrf2 in cancers: A double-edged sword. Cancer Med. 2019, 8, 2252-2267. [CrossRef]

91. Liu, Y.; Pang, Y.; Caisova, V.; Ding, J.; Yu, D.; Zhou, Y.; Huynh, T.T.; Ghayee, H.; Pacak, K.; Yang, C. Targeting NRF2-Governed Glutathione Synthesis for SDHB-Mutated Pheochromocytoma and Paraganglioma. Cancers 2020, 12, 280. [CrossRef]

92. Liu, Y.; Lu, Y.; Celiku, O.; Li, A.; Wu, Q.; Zhou, Y.; Yang, C. Targeting IDH1-Mutated Malignancies with NRF2 Blockade. J. Natl. Cancer Inst. 2019, 111, 1033-1041. [CrossRef] [PubMed]

93. Benarroch, E.E. Nrf2, cellular redox regulation, and neurologic implications. Neurology 2017, 88, $1942-1950$. [CrossRef] [PubMed]

94. Dinkova-Kostova, A.T.; Kostov, R.V.; Kazantsev, A.G. The role of Nrf2 signaling in counteracting neurodegenerative diseases. FEBS J. 2018, 285, 3576-3590. [CrossRef] [PubMed]

95. Abdalkader, M.; Lampinen, R.; Kanninen, K.M.; Malm, T.M.; Liddell, J.R. Targeting Nrf2 to Suppress Ferroptosis and Mitochondrial Dysfunction in Neurodegeneration. Front. Neurosci. 2018, 12, 466. [CrossRef]

96. Basak, P.; Sadhukhan, P.; Sarkar, P.; Sil, P.C. Perspectives of the Nrf-2 signaling pathway in cancer progression and therapy. Toxicol. Rep. 2017, 4, 306-318. [CrossRef]

97. Menegon, S.; Columbano, A.; Giordano, S. The Dual Roles of NRF2 in Cancer. Trends Mol. Med. 2016, 22, 578-593. [CrossRef]

98. Taguchi, K.; Yamamoto, M. The KEAP1-NRF2 System in Cancer. Front. Oncol. 2017, 7, 85. [CrossRef]

99. Kitamura, H.; Motohashi, H. NRF2 addiction in cancer cells. Cancer Sci. 2018, 109, 900-911. [CrossRef]

100. Ramsey, C.P.; Glass, C.A.; Montgomery, M.B.; Lindl, K.A.; Ritson, G.P.; Chia, L.A.; Hamilton, R.L.; Chu, C.T.; Jordan-Sciutto, K.L. Expression of Nrf2 in neurodegenerative diseases. J. Neuropathol. Exp. Neurol. 2007, 66, 75-85. [CrossRef]

101. Sarlette, A.; Krampfl, K.; Grothe, C.; Neuhoff, N.; Dengler, R.; Petri, S. Nuclear erythroid 2-related factor 2-antioxidative response element signaling pathway in motor cortex and spinal cord in amyotrophic lateral sclerosis. J. Neuropathol. Exp. Neurol. 2008, 67, 1055-1062. [CrossRef]

102. Brandes, M.S.; Gray, N.E. NRF2 as a Therapeutic Target in Neurodegenerative Diseases. ASN Neuro 2020, 12, 1759091419899782. [CrossRef] [PubMed]

103. Sbodio, J.I.; Snyder, S.H.; Paul, B.D. Redox Mechanisms in Neurodegeneration: From Disease Outcomes to Therapeutic Opportunities. Antioxid. Redox Signal. 2019, 30, 1450-1499. [CrossRef] [PubMed]

104. Cossée, M.; Schmitt, M.; Campuzano, V.; Reutenauer, L.; Moutou, C.; Mandel, J.L.; Koenig, M. Evolution of the Friedreich's ataxia trinucleotide repeat expansion: Founder effect and premutations. Proc. Natl. Acad. Sci. USA 1997, 94, 7452-7457. [CrossRef] [PubMed]

105. Kim, E.; Napierala, M.; Dent, S.Y. Hyperexpansion of GAA repeats affects post-initiation steps of FXN transcription in Friedreich's ataxia. Nucleic Acids Res. 2011, 39, 8366-8377. [CrossRef]

106. Koeppen, A.H. Friedreich's ataxia: Pathology, pathogenesis, and molecular genetics. J. Neurol. Sci. 2011, 303, 1-12. [CrossRef] 
107. Pandolfo, M.; Pastore, A. The pathogenesis of Friedreich ataxia and the structure and function of frataxin. J. Neurol. 2009, 256 (Suppl. 1), 9-17. [CrossRef]

108. Parkinson, M.H.; Boesch, S.; Nachbauer, W.; Mariotti, C.; Giunti, P. Clinical features of Friedreich's ataxia: Classical and atypical phenotypes. J. Neurochem. 2013, 126 (Suppl. 1), 103-117. [CrossRef]

109. Puccio, H.; Simon, D.; Cossee, M.; Criqui-Filipe, P.; Tiziano, F.; Melki, J.; Hindelang, C.; Matyas, R.; Rustin, P.; Koenig, M. Mouse models for Friedreich ataxia exhibit cardiomyopathy, sensory nerve defect and Fe-S enzyme deficiency followed by intramitochondrial iron deposits. Nat. Genet. 2001, 27, 181-186. [CrossRef]

110. Anzovino, A.; Lane, D.J.; Huang, M.L.; Richardson, D.R. Fixing frataxin: 'ironing out' the metabolic defect in Friedreich's ataxia. Br. J. Pharmacol. 2014, 171, 2174-2190. [CrossRef]

111. Vaubel, R.A.; Isaya, G. Iron-sulfur cluster synthesis, iron homeostasis and oxidative stress in Friedreich ataxia. Mol. Cell. Neurosci. 2013, 55, 50-61. [CrossRef]

112. Koenig, M.; Mandel, J.L. Deciphering the cause of Friedreich ataxia. Curr. Opin. Neurobiol. 1997, 7, 689-694. [CrossRef]

113. Gomes, C.M.; Santos, R. Neurodegeneration in Friedreich's ataxia: From defective frataxin to oxidative stress. Oxid. Med. Cell. Longev. 2013, 2013, 487534. [CrossRef]

114. Carletti, B.; Piemonte, F. Friedreich's Ataxia: A Neuronal Point of View on the Oxidative Stress Hypothesis. Antioxidants 2014, 3, 592-603. [CrossRef]

115. Lupoli, F.; Vannocci, T.; Longo, G.; Niccolai, N.; Pastore, A. The role of oxidative stress in Friedreich's ataxia. FEBS Lett. 2018, 592, 718-727. [CrossRef]

116. Anzovino, A.; Chiang, S.; Brown, B.E.; Hawkins, C.L.; Richardson, D.R.; Huang, M.L. Molecular Alterations in a Mouse Cardiac Model of Friedreich Ataxia: An Impaired Nrf2 Response Mediated via Upregulation of Keap1 and Activation of the Gsk3 $\beta$ Axis. Am. J. Pathol. 2017, 187, 2858-2875. [CrossRef] [PubMed]

117. Paupe, V.; Dassa, E.P.; Goncalves, S.; Auchere, F.; Lonn, M.; Holmgren, A.; Rustin, P. Impaired nuclear Nrf2 translocation undermines the oxidative stress response in Friedreich ataxia. PLoS ONE 2009, 4, e4253. [CrossRef]

118. D’Oria, V.; Petrini, S.; Travaglini, L.; Priori, C.; Piermarini, E.; Petrillo, S.; Carletti, B.; Bertini, E.; Piemonte, F. Frataxin deficiency leads to reduced expression and impaired translocation of NF-E2-related factor (Nrf2) in cultured motor neurons. Int. J. Mol. Sci. 2013, 14, 7853-7865. [CrossRef]

119. Shan, Y.; Schoenfeld, R.A.; Hayashi, G.; Napoli, E.; Akiyama, T.; Iodi Carstens, M.; Carstens, E.E.; Pook, M.A.; Cortopassi, G.A. Frataxin deficiency leads to defects in expression of antioxidants and Nrf2 expression in dorsal root ganglia of the Friedreich's ataxia YG8R mouse model. Antioxid. Redox Signal. 2013, 19, 1481-1493. [CrossRef] [PubMed]

120. Emond, M.; Lepage, G.; Vanasse, M.; Pandolfo, M. Increased levels of plasma malondialdehyde in Friedreich ataxia. Neurology 2000, 55, 1752-1753. [CrossRef] [PubMed]

121. Schulz, J.B.; Dehmer, T.; Schöls, L.; Mende, H.; Hardt, C.; Vorgerd, M.; Bürk, K.; Matson, W.; Dichgans, J.; Beal, M.F.; et al. Oxidative stress in patients with Friedreich ataxia. Neurology 2000, 55, 1719-1721. [CrossRef]

122. Tozzi, G.; Nuccetelli, M.; Lo Bello, M.; Bernardini, S.; Bellincampi, L.; Ballerini, S.; Gaeta, L.M.; Casali, C.; Pastore, A.; Federici, G.; et al. Antioxidant enzymes in blood of patients with Friedreich's ataxia. Arch. Dis. Child. 2002, 86, 376-379. [CrossRef] [PubMed]

123. Johnson, W.M.; Wilson-Delfosse, A.L.; Mieyal, J.J. Dysregulation of glutathione homeostasis in neurodegenerative diseases. Nutrients 2012, 4, 1399-1440. [CrossRef] [PubMed]

124. Cotticelli, M.G.; Crabbe, A.M.; Wilson, R.B.; Shchepinov, M.S. Insights into the role of oxidative stress in the pathology of Friedreich ataxia using peroxidation resistant polyunsaturated fatty acids. Redox Biol. 2013, 1, 398-404. [CrossRef] [PubMed]

125. Cotticelli, M.G.; Xia, S.; Lin, D.; Lee, T.; Terrab, L.; Wipf, P.; Huryn, D.M.; Wilson, R.B. Ferroptosis as a Novel Therapeutic Target for Friedreich's Ataxia. J. Pharmacol. Exp. Ther. 2019, 369, 47-54. [CrossRef] [PubMed]

126. Abeti, R.; Parkinson, M.H.; Hargreaves, I.P.; Angelova, P.R.; Sandi, C.; Pook, M.A.; Giunti, P.; Abramov, A.Y. 'Mitochondrial energy imbalance and lipid peroxidation cause cell death in Friedreich's ataxia'. Cell Death Dis. 2016, 7, e2237. [CrossRef]

127. Kajarabille, N.; Latunde-Dada, G.O. Programmed Cell-Death by Ferroptosis: Antioxidants as Mitigators. Int. J. Mol. Sci. 2019, 20. [CrossRef] 
128. Esteras, N.; Dinkova-Kostova, A.T.; Abramov, A.Y. Nrf2 activation in the treatment of neurodegenerative diseases: A focus on its role in mitochondrial bioenergetics and function. Biol. Chem. 2016, 397, 383-400. [CrossRef]

129. Kensler, T.W.; Wakabayashi, N.; Biswal, S. Cell survival responses to environmental stresses via the Keap1-Nrf2-ARE pathway. Annu. Rev. Pharmacol. Toxicol. 2007, 47, 89-116. [CrossRef]

130. Klomparens, E.A.; Ding, Y. The neuroprotective mechanisms and effects of sulforaphane. Brain Circ. 2019, 5, 74-83. [CrossRef]

131. Uddin, M.S.; Mamun, A.A.; Jakaria, M.; Thangapandiyan, S.; Ahmad, J.; Rahman, M.A.; Mathew, B.; Abdel-Daim, M.M.; Aleya, L. Emerging promise of sulforaphane-mediated Nrf2 signaling cascade against neurological disorders. Sci. Total Environ. 2020, 707, 135624. [CrossRef]

132. Scannevin, R.H.; Chollate, S.; Jung, M.Y.; Shackett, M.; Patel, H.; Bista, P.; Zeng, W.; Ryan, S.; Yamamoto, M.; Lukashev, M.; et al. Fumarates promote cytoprotection of central nervous system cells against oxidative stress via the nuclear factor (erythroid-derived 2)-like 2 pathway. J. Pharmacol. Exp. Ther. 2012, 341, 274-284. [CrossRef] [PubMed]

133. Montes Diaz, G.; Hupperts, R.; Fraussen, J.; Somers, V. Dimethyl fumarate treatment in multiple sclerosis: Recent advances in clinical and immunological studies. Autoimmun. Rev. 2018, 17, 1240-1250. [CrossRef] [PubMed]

134. Ranea-Robles, P.; Launay, N.; Ruiz, M.; Calingasan, N.Y.; Dumont, M.; Naudi, A.; Portero-Otin, M.; Pamplona, R.; Ferrer, I.; Beal, M.F.; et al. Aberrant regulation of the GSK-3beta/NRF2 axis unveils a novel therapy for adrenoleukodystrophy. EMBO Mol. Med. 2018, 10, e8604. [CrossRef] [PubMed]

135. Petrillo, S.; Piermarini, E.; Pastore, A.; Vasco, G.; Schirinzi, T.; Carrozzo, R.; Bertini, E.; Piemonte, F. Nrf2-Inducers Counteract Neurodegeneration in Frataxin-Silenced Motor Neurons: Disclosing New Therapeutic Targets for Friedreich's Ataxia. Int. J. Mol. Sci. 2017, 18, 2173. [CrossRef]

136. Jasoliya, M.; Sacca, F.; Sahdeo, S.; Chedin, F.; Pane, C.; Brescia Morra, V.; Filla, A.; Pook, M.; Cortopassi, G. Dimethyl fumarate dosing in humans increases frataxin expression: A potential therapy for Friedreich's Ataxia. PLoS ONE 2019, 14, e0217776. [CrossRef]

137. Sahdeo, S.; Scott, B.D.; McMackin, M.Z.; Jasoliya, M.; Brown, B.; Wulff, H.; Perlman, S.L.; Pook, M.A.; Cortopassi, G.A. Dyclonine rescues frataxin deficiency in animal models and buccal cells of patients with Friedreich's ataxia. Hum. Mol. Genet. 2014, 23, 6848-6862. [CrossRef]

138. Clay, A.; Hearle, P.; Schadt, K.; Lynch, D.R. New developments in pharmacotherapy for Friedreich ataxia. Expert Opin. Pharmacother. 2019, 20, 1855-1867. [CrossRef]

139. Hausse, A.O.; Aggoun, Y.; Bonnet, D.; Sidi, D.; Munnich, A.; Rotig, A.; Rustin, P. Idebenone and reduced cardiac hypertrophy in Friedreich's ataxia. Heart 2002, 87, 346-349. [CrossRef]

140. Di Prospero, N.A.; Baker, A.; Jeffries, N.; Fischbeck, K.H. Neurological effects of high-dose idebenone in patients with Friedreich's ataxia: A randomised, placebo-controlled trial. Lancet Neurol. 2007, 6, 878-886. [CrossRef]

141. Montenegro, L.; Turnaturi, R.; Parenti, C.; Pasquinucci, L. Idebenone: Novel Strategies to Improve Its Systemic and Local Efficacy. Nanomaterials 2018, 8, 87. [CrossRef] [PubMed]

142. Lynch, D.R.; Farmer, J.; Hauser, L.; Blair, I.A.; Wang, Q.Q.; Mesaros, C.; Snyder, N.; Boesch, S.; Chin, M.; Delatycki, M.B.; et al. Safety, pharmacodynamics, and potential benefit of omaveloxolone in Friedreich ataxia. Ann. Clin. Transl. Neurol. 2019, 6, 15-26. [CrossRef] [PubMed]

143. Zesiewicz, T.; Salemi, J.L.; Perlman, S.; Sullivan, K.L.; Shaw, J.D.; Huang, Y.; Isaacs, C.; Gooch, C.; Lynch, D.R.; Klein, M.B. Double-blind, randomized and controlled trial of EPI-743 in Friedreich's ataxia. Neurodegener. Dis. Manag. 2018, 8, 233-242. [CrossRef] [PubMed]

144. Hagerman, R.J.; Berry-Kravis, E.; Hazlett, H.C.; Bailey, D.B.; Moine, H.; Kooy, R.F.; Tassone, F.; Gantois, I.; Sonenberg, N.; Mandel, J.L.; et al. Fragile X syndrome. Nat. Rev. Dis. Primers 2017, 3, 17065. [CrossRef]

145. Bell, M.V.; Hirst, M.C.; Nakahori, Y.; MacKinnon, R.N.; Roche, A.; Flint, T.J.; Jacobs, P.A.; Tommerup, N.; Tranebjaerg, L.; Froster-Iskenius, U.; et al. Physical mapping across the fragile X: Hypermethylation and clinical expression of the fragile $\mathrm{X}$ syndrome. Cell 1991, 64, 861-866. [CrossRef]

146. Myrick, L.K.; Nakamoto-Kinoshita, M.; Lindor, N.M.; Kirmani, S.; Cheng, X.; Warren, S.T. Fragile X syndrome due to a missense mutation. Eur. J. Hum. Genet. 2014, 22, 1185-1189. [CrossRef] 
147. Quartier, A.; Poquet, H.; Gilbert-Dussardier, B.; Rossi, M.; Casteleyn, A.S.; Portes, V.D.; Feger, C.; Nourisson, E.; Kuentz, P.; Redin, C.; et al. Intragenic FMR1 disease-causing variants: A significant mutational mechanism leading to Fragile-X syndrome. Eur. J. Hum. Genet. 2017, 25, 423-431. [CrossRef] [PubMed]

148. Jiraanont, P.; Kumar, M.; Tang, H.-T.; Espinal, G.; Hagerman, P.J.; Hagerman, R.J.; Chutabhakdikul, N.; Tassone, F. Size and methylation mosaicism in males with Fragile X syndrome. Expert Rev. Mol. Diagn. 2017, 17, 1023-1032. [CrossRef]

149. Abbeduto, L.; McDuffie, A.; Thurman, A.J. The fragile X syndrome-autism comorbidity: What do we really know? Front. Genet. 2014, 5, 355. [CrossRef]

150. Dyer-Friedman, J.; Glaser, B.; Hessl, D.; Johnston, C.; Huffman, L.C.; Taylor, A.; Wisbeck, J.; Reiss, A.L. Genetic and environmental influences on the cognitive outcomes of children with fragile $X$ syndrome. J. Am. Acad. Child Adolesc. Psychiatry 2002, 41, 237-244. [CrossRef]

151. Loesch, D.Z.; Huggins, R.M.; Hagerman, R.J. Phenotypic variation and FMRP levels in fragile X. Ment. Retard. Dev. Disabil. Res. Rev. 2004, 10, 31-41. [CrossRef]

152. Bartholomay, K.L.; Lee, C.H.; Bruno, J.L.; Lightbody, A.A.; Reiss, A.L. Closing the Gender Gap in Fragile X Syndrome: Review on Females with FXS and Preliminary Research Findings. Brain Sci. 2019, 9, 11. [CrossRef] [PubMed]

153. Bardoni, B.; Schenck, A.; Mandel, J.-L. The Fragile X mental retardation protein. Brain Res. Bull. 2001, 56, 375-382. [CrossRef]

154. Devys, D.; Lutz, Y.; Rouyer, N.; Bellocq, J.-P.; Mandel, J.-L. The FMR-1 protein is cytoplasmic, most abundant in neurons and appears normal in carriers of a fragile X premutation. Nat. Genet. 1993, 4, 335-340. [CrossRef] [PubMed]

155. Feng, Y.; Gutekunst, C.A.; Eberhart, D.E.; Yi, H.; Warren, S.T.; Hersch, S.M. Fragile X mental retardation protein: Nucleocytoplasmic shuttling and association with somatodendritic ribosomes. J. Neurosci. 1997, 17, 1539-1547. [CrossRef]

156. Ferrari, F.; Mercaldo, V.; Piccoli, G.; Sala, C.; Cannata, S.; Achsel, T.; Bagni, C. The fragile X mental retardation protein-RNP granules show an mGluR-dependent localization in the post-synaptic spines. Mol. Cell. Neurosci. 2007, 34, 343-354. [CrossRef]

157. Dictenberg, J.B.; Swanger, S.A.; Antar, L.N.; Singer, R.H.; Bassell, G.J. A direct role for FMRP in activity-dependent dendritic mRNA transport links filopodial-spine morphogenesis to fragile $\mathrm{X}$ syndrome. Dev. Cell 2008, 14, 926-939. [CrossRef]

158. Huber, K.M.; Gallagher, S.M.; Warren, S.T.; Bear, M.F. Altered synaptic plasticity in a mouse model of fragile X mental retardation. Proc. Natl. Acad. Sci. USA 2002, 99, 7746-7750. [CrossRef]

159. Nakamoto, M.; Nalavadi, V.; Epstein, M.P.; Narayanan, U.; Bassell, G.J.; Warren, S.T. Fragile X mental retardation protein deficiency leads to excessive mGluR5-dependent internalization of AMPA receptors. Proc. Natl. Acad. Sci. USA 2007, 104, 15537-15542. [CrossRef]

160. Eadie, B.D.; Cushman, J.; Kannangara, T.S.; Fanselow, M.S.; Christie, B.R. NMDA receptor hypofunction in the dentate gyrus and impaired context discrimination in adult Fmr1 knockout mice. Hippocampus 2012, 22, 241-254. [CrossRef]

161. Centonze, D.; Rossi, S.; Mercaldo, V.; Napoli, I.; Ciotti, M.T.; De Chiara, V.; Musella, A.; Prosperetti, C.; Calabresi, P.; Bernardi, G.; et al. Abnormal striatal GABA transmission in the mouse model for the fragile $\mathrm{X}$ syndrome. Biol. Psychiatry 2008, 63, 963-973. [CrossRef]

162. Fernandez, E.; Rajan, N.; Bagni, C. The FMRP regulon: From targets to disease convergence. Front. Neurosci. 2013, 7, 191. [CrossRef] [PubMed]

163. Brown, V.; Jin, P.; Ceman, S.; Darnell, J.C.; O’Donnell, W.T.; Tenenbaum, S.A.; Jin, X.; Feng, Y.; Wilkinson, K.D.; Keene, J.D.; et al. Microarray identification of FMRP-associated brain mRNAs and altered mRNA translational profiles in fragile $X$ syndrome. Cell 2001, 107, 477-487. [CrossRef]

164. Napoli, I.; Mercaldo, V.; Boyl, P.P.; Eleuteri, B.; Zalfa, F.; De Rubeis, S.; Di Marino, D.; Mohr, E.; Massimi, M.; Falconi, M.; et al. The fragile $\mathrm{X}$ syndrome protein represses activity-dependent translation through CYFIP1, a new 4E-BP. Cell 2008, 134, 1042-1054. [CrossRef] [PubMed]

165. Narayanan, U.; Nalavadi, V.; Nakamoto, M.; Pallas, D.C.; Ceman, S.; Bassell, G.J.; Warren, S.T. FMRP phosphorylation reveals an immediate-early signaling pathway triggered by group I mGluR and mediated by PP2A. J. Neurosci. 2007, 27, 14349-14357. [CrossRef] 
166. Muddashetty, R.S.; Kelić, S.; Gross, C.; Xu, M.; Bassell, G.J. Dysregulated metabotropic glutamate receptor-dependent translation of AMPA receptor and postsynaptic density-95 mRNAs at synapses in a mouse model of fragile X syndrome. J. Neurosci. 2007, 27, 5338-5348. [CrossRef] [PubMed]

167. Li, J.; Pelletier, M.R.; Perez Velazquez, J.L.; Carlen, P.L. Reduced cortical synaptic plasticity and GluR1 expression associated with fragile $\mathrm{X}$ mental retardation protein deficiency. Mol. Cell. Neurosci. 2002, 19, 138-151. [CrossRef]

168. Serrano, F.; Klann, E. Reactive oxygen species and synaptic plasticity in the aging hippocampus. Ageing Res. Rev. 2004, 3, 431-443. [CrossRef]

169. Sidorov, M.S.; Auerbach, B.D.; Bear, M.F. Fragile X mental retardation protein and synaptic plasticity. Mol. Brain 2013, 6, 15. [CrossRef]

170. Chauhan, A.; Chauhan, V. Oxidative stress in autism. Pathophysiology 2006, 13, 171-181. [CrossRef]

171. Gingrich, J.A. Oxidative stress is the new stress. Nat. Med. 2005, 11, 1281-1282. [CrossRef]

172. Bouayed, J.; Rammal, H.; Soulimani, R. Oxidative stress and anxiety: Relationship and cellular pathways. Oxid. Med. Cell. Longev. 2009, 2, 63-67. [CrossRef]

173. Tönnies, E.; Trushina, E. Oxidative Stress, Synaptic Dysfunction, and Alzheimer's Disease. J. Alzheimers Dis. 2017, 57, 1105-1121. [CrossRef]

174. El Bekay, R.; Romero-Zerbo, Y.; Decara, J.; Sanchez-Salido, L.; Del Arco-Herrera, I.; Rodríguez-de Fonseca, F.; de Diego-Otero, Y. Enhanced markers of oxidative stress, altered antioxidants and NADPH-oxidase activation in brains from Fragile $X$ mental retardation 1-deficient mice, a pathological model for Fragile $X$ syndrome. Eur. J. Neurosci. 2007, 26, 3169-3180. [CrossRef] [PubMed]

175. Miyashiro, K.Y.; Beckel-Mitchener, A.; Purk, T.P.; Becker, K.G.; Barret, T.; Liu, L.; Carbonetto, S.; Weiler, I.J.; Greenough, W.T.; Eberwine, J. RNA cargoes associating with FMRP reveal deficits in cellular functioning in Fmr1 null mice. Neuron 2003, 37, 417-431. [CrossRef]

176. Bechara, E.G.; Didiot, M.C.; Melko, M.; Davidovic, L.; Bensaid, M.; Martin, P.; Castets, M.; Pognonec, P.; Khandjian, E.W.; Moine, H.; et al. A novel function for fragile X mental retardation protein in translational activation. PLoS Biol. 2009, 7, e16. [CrossRef] [PubMed]

177. Cuadrado, A.; Martín-Moldes, Z.; Ye, J.; Lastres-Becker, I. Transcription factors NRF2 and NF- $k B$ are coordinated effectors of the Rho family, GTP-binding protein RAC1 during inflammation. J Biol. Chem. 2014, 289, 15244-15258. [CrossRef]

178. Marei, H.; Malliri, A. Rac1 in human diseases: The therapeutic potential of targeting Rac1 signaling regulatory mechanisms. Small GTPases 2017, 8, 139-163. [CrossRef]

179. Tanaka, T.; Terada, M.; Ariyoshi, K.; Morimoto, K. Monocyte chemoattractant protein-1/CC chemokine ligand 2 enhances apoptotic cell removal by macrophages through Rac1 activation. Biochem. Biophys. Res. Commun. 2010, 399, 677-682. [CrossRef]

180. Wang, X.; Zhang, F.; Chen, F.; Liu, D.; Zheng, Y.; Zhang, Y.; Dong, C.; Su, B. MEKK3 regulates IFN-gamma production in T cells through the Rac1/2-dependent MAPK cascades. J. Immunol. 2011, 186, 5791-5800. [CrossRef]

181. Salazar, M.; Rojo, A.I.; Velasco, D.; de Sagarra, R.M.; Cuadrado, A. Glycogen synthase kinase-3beta inhibits the xenobiotic and antioxidant cell response by direct phosphorylation and nuclear exclusion of the transcription factor Nrf2. J. Biol. Chem. 2006, 281, 14841-14851. [CrossRef]

182. Beitel, L.; Alvarado, C.; Mokhtar, S.; Paliouras, M.; Trifiro, M. Mechanisms Mediating Spinal and Bulbar Muscular Atrophy: Investigations into Polyglutamine-Expanded Androgen Receptor Function and Dysfunction. Front. Neurol. 2013, 4, 53. [CrossRef] [PubMed]

183. Rhodes, L.E.; Freeman, B.K.; Auh, S.; Kokkinis, A.D.; La Pean, A.; Chen, C.; Lehky, T.J.; Shrader, J.A.; Levy, E.W.; Harris-Love, M.; et al. Clinical features of spinal and bulbar muscular atrophy. Brain J. Neurol. 2009, 132, 3242-3251. [CrossRef] [PubMed]

184. Dejager, S.; Bry-Gauillard, H.; Bruckert, E.; Eymard, B.; Salachas, F.; LeGuern, E.; Tardieu, S.; Chadarevian, R.; Giral, P.; Turpin, G. A comprehensive endocrine description of Kennedy's disease revealing androgen insensitivity linked to CAG repeat length. J. Clin. Endocrinol. Metab. 2002, 87, 3893-3901. [CrossRef] [PubMed]

185. Antonini, G.; Gragnani, F.; Romaniello, A.; Pennisi, E.M.; Morino, S.; Ceschin, V.; Santoro, L.; Cruccu, G. Sensory involvement in spinal-bulbar muscular atrophy (Kennedy's disease). Muscle Nerve 2000, 23, $252-258$. [CrossRef] 
186. La Spada, A.R.; Wilson, E.M.; Lubahn, D.B.; Harding, A.E.; Fischbeck, K.H. Androgen receptor gene mutations in X-linked spinal and bulbar muscular atrophy. Nature 1991, 352, 77-79. [CrossRef]

187. Pellegrini, M.; Bulzomi, P.; Lecis, M.; Leone, S.; Campesi, I.; Franconi, F.; Marino, M. Endocrine Disruptors Differently Influence Estrogen Receptor $\beta$ and Androgen Receptor in Male and Female Rat VSMC. J. Cell. Physiol. 2014, 229, 1061-1068. [CrossRef]

188. Rusmini, P.; Sau, D.; Crippa, V.; Palazzolo, I.; Simonini, F.; Onesto, E.; Martini, L.; Poletti, A. Aggregation and proteasome: The case of elongated polyglutamine aggregation in spinal and bulbar muscular atrophy. Neurobiol. Aging 2007, 28, 1099-1111. [CrossRef]

189. Schindler, M.; Fabre, C.; de Weille, J.; Carreau, S.; Mersel, M.; Bakalara, N. Disruption of Nongenomic Testosterone Signaling in a Model of Spinal and Bulbar Muscular Atrophy. Mol. Endocrinol. 2012, 26, 1102-1116. [CrossRef]

190. Davies, P.; Watt, K.; Kelly, S.M.; Clark, C.; Price, N.C.; McEwan, I.J. Consequences of poly-glutamine repeat length for the conformation and folding of the androgen receptor amino-terminal domain. J. Mol. Endocrinol. 2008, 41, 301-314. [CrossRef]

191. Lieberman, A.P.; Harmison, G.; Strand, A.D.; Olson, J.M.; Fischbeck, K.H. Altered transcriptional regulation in cells expressing the expanded polyglutamine androgen receptor. Hum. Mol. Genet. 2002, 11, 1967-1976. [CrossRef]

192. McCampbell, A.; Taylor, J.P.; Taye, A.A.; Robitschek, J.; Li, M.; Walcott, J.; Merry, D.; Chai, Y.; Paulson, H.; Sobue, G.; et al. CREB-binding protein sequestration by expanded polyglutamine. Hum. Mol. Genet. 2000, 9 , 2197-2202. [CrossRef] [PubMed]

193. Schmidt, B.J.; Greenberg, C.R.; Allingham-Hawkins, D.J.; Spriggs, E.L. Expression of X-linked bulbospinal muscular atrophy (Kennedy disease) in two homozygous women. Neurology 2002, 59, 770-772. [CrossRef] [PubMed]

194. Takeyama, K.; Ito, S.; Yamamoto, A.; Tanimoto, H.; Furutani, T.; Kanuka, H.; Miura, M.; Tabata, T.; Kato, S. Androgen-dependent neurodegeneration by polyglutamine-expanded human androgen receptor in Drosophila. Neuron 2002, 35, 855-864. [CrossRef]

195. Katsuno, M.; Adachi, H.; Kume, A.; Li, M.; Nakagomi, Y.; Niwa, H.; Sang, C.; Kobayashi, Y.; Doyu, M.; Sobue, $\mathrm{G}$. Testosterone reduction prevents phenotypic expression in a transgenic mouse model of spinal and bulbar muscular atrophy. Neuron 2002, 35, 843-854. [CrossRef]

196. Cary, G.A.; La Spada, A.R. Androgen Receptor Function in Motor Neuron Survival and Degeneration. Phys. Med. Rehabil. Clin. N. Am. 2008, 19, 479-494. [CrossRef] [PubMed]

197. Yamamoto, M.; Mitsuma, N.; Inukai, A.; Ito, Y.; Li, M.; Mitsuma, T.; Sobue, G. Expression of GDNF and GDNFR-alpha mRNAs in muscles of patients with motor neuron diseases. Neurochem. Res. 1999, 24, 785-790. [CrossRef]

198. Yu, Z.; Dadgar, N.; Albertelli, M.; Gruis, K.; Jordan, C.; Robins, D.M.; Lieberman, A.P. Androgen-dependent pathology demonstrates myopathic contribution to the Kennedy disease phenotype in a mouse knock-in model. J. Clin. Investig. 2006, 116, 2663-2672. [CrossRef]

199. Sopher, B.L.; Thomas, P.S., Jr.; LaFevre-Bernt, M.A.; Holm, I.E.; Wilke, S.A.; Ware, C.B.; Jin, L.W.; Libby, R.T.; Ellerby, L.M.; La Spada, A.R. Androgen receptor YAC transgenic mice recapitulate SBMA motor neuronopathy and implicate VEGF164 in the motor neuron degeneration. Neuron 2004, 41, 687-699. [CrossRef]

200. Ranganathan, S.; Harmison, G.G.; Meyertholen, K.; Pennuto, M.; Burnett, B.G.; Fischbeck, K.H. Mitochondrial abnormalities in spinal and bulbar muscular atrophy. Hum. Mol. Genet. 2009, 18, 27-42. [CrossRef]

201. Finsterer, J.; Mishra, A.; Wakil, S.; Pennuto, M.; Soraru, G. Mitochondrial implications in bulbospinal muscular atrophy (Kennedy disease). Amyotroph. Lateral Scler. Frontotemporal Degener. 2015, 17, 112-118. [CrossRef]

202. Gavrilova-Jordan, L.P.; Price, T.M. Actions of steroids in mitochondria. Semin. Reprod. Med. 2007, 25, 154-164. [CrossRef] [PubMed]

203. Stenoien, D.L.; Cummings, C.J.; Adams, H.P.; Mancini, M.G.; Patel, K.; DeMartino, G.N.; Marcelli, M.; Weigel, N.L.; Mancini, M.A. Polyglutamine-expanded androgen receptors form aggregates that sequester heat shock proteins, proteasome components and SRC-1, and are suppressed by the HDJ-2 chaperone. Hum. Mol. Genet. 1999, 8, 731-741. [CrossRef] [PubMed]

204. Simeoni, S.; Mancini, M.A.; Stenoien, D.L.; Marcelli, M.; Weigel, N.L.; Zanisi, M.; Martini, L.; Poletti, A. Motoneuronal cell death is not correlated with aggregate formation of androgen receptors containing an elongated polyglutamine tract. Hum. Mol. Genet. 2000, 9, 133-144. [CrossRef] [PubMed] 
205. Sisodia, S.S. Nuclear inclusions in glutamine repeat disorders: Are they pernicious, coincidental, or beneficial? Cell 1998, 95, 1-4. [CrossRef]

206. Piccioni, F.; Pinton, P.; Simeoni, S.; Pozzi, P.; Fascio, U.; Vismara, G.; Martini, L.; Rizzuto, R.; Poletti, A. Androgen receptor with elongated polyglutamine tract forms aggregates that alter axonal trafficking and mitochondrial distribution in motor neuronal processes. FASEB J. 2002, 16, 1418-1420. [CrossRef]

207. Beauchemin, A.M.J.; Gottlieb, B.; Beitel, L.K.; Elhaji, Y.A.; Pinsky, L.; Trifiro, M.A. Cytochrome c oxidase subunit $\mathrm{Vb}$ interacts with human androgen receptor: A potential mechanism for neurotoxicity in spinobulbar muscular atrophy. Brain Res. Bull. 2001, 56, 285-297. [CrossRef]

208. Malik, B.; Devine, H.; Patani, R.; La Spada, A.R.; Hanna, M.G.; Greensmith, L. Gene expression analysis reveals early dysregulation of disease pathways and links Chmp7 to pathogenesis of spinal and bulbar muscular atrophy. Sci. Rep. 2019, 9, 3539. [CrossRef]

209. Alavez, S.; Vantipalli, M.C.; Zucker, D.J.S.; Klang, I.M.; Lithgow, G.J. Amyloid-binding compounds maintain protein homeostasis during ageing and extend lifespan. Nature 2011, 472, 226-229. [CrossRef]

210. Calamini, B.; Silva, M.C.; Madoux, F.; Hutt, D.M.; Khanna, S.; Chalfant, M.A.; Saldanha, S.A.; Hodder, P.; Tait, B.D.; Garza, D.; et al. Small-molecule proteostasis regulators for protein conformational diseases. Nat. Chem. Biol. 2012, 8, 185-196. [CrossRef]

211. Porat, Y.; Abramowitz, A.; Gazit, E. Inhibition of amyloid fibril formation by polyphenols: Structural similarity and aromatic interactions as a common inhibition mechanism. Chem. Biol. Drug Des. 2006, 67, 27-37. [CrossRef]

212. Dinkova-Kostova, A.T.; Massiah, M.A.; Bozak, R.E.; Hicks, R.J.; Talalay, P. Potency of Michael reaction acceptors as inducers of enzymes that protect against carcinogenesis depends on their reactivity with sulfhydryl groups. Proc. Natl. Acad. Sci. USA 2001, 98, 3404-3409. [CrossRef] [PubMed]

213. Mishra, P.; Paital, B.; Jena, S.; Swain, S.S.; Kumar, S.; Yadav, M.K.; Chainy, G.B.N.; Samanta, L. Possible activation of NRF2 by Vitamin E/Curcumin against altered thyroid hormone induced oxidative stress via $\mathrm{NF} \kappa \mathrm{B} / \mathrm{AKT} / \mathrm{mTOR} / \mathrm{KEAP1}$ signalling in rat heart. Sci. Rep. 2019, 9, 7408. [CrossRef] [PubMed]

214. Yang, Z.; Chang, Y.-J.; Yu, I.C.; Yeh, S.; Wu, C.-C.; Miyamoto, H.; Merry, D.E.; Sobue, G.; Chen, L.-M.; Chang, S.-S.; et al. ASC-J9 ameliorates spinal and bulbar muscular atrophy phenotype via degradation of androgen receptor. Nat. Med. 2007, 13, 348-353. [CrossRef] [PubMed]

215. Bott, L.C.; Badders, N.M.; Chen, K.L.; Harmison, G.G.; Bautista, E.; Shih, C.C.; Katsuno, M.; Sobue, G.; Taylor, J.P.; Dantuma, N.P.; et al. A small-molecule Nrf1 and Nrf2 activator mitigates polyglutamine toxicity in spinal and bulbar muscular atrophy. Hum. Mol. Genet. 2016, 25, 1979-1989. [CrossRef]

216. Furtado, S.; Suchowersky, O.; Rewcastle, B.; Graham, L.; Klimek, M.L.; Garber, A. Relationship between trinucleotide repeats and neuropathological changes in Huntington's disease. Ann. Neurol. 1996, 39, 132-136. [CrossRef]

217. Snell, R.G.; MacMillan, J.C.; Cheadle, J.P.; Fenton, I.; Lazarou, L.P.; Davies, P.; MacDonald, M.E.; Gusella, J.F.; Harper, P.S.; Shaw, D.J. Relationship between trinucleotide repeat expansion and phenotypic variation in Huntington's disease. Nat. Genet. 1993, 4, 393-397. [CrossRef] [PubMed]

218. The Huntington's Disease Collaborative Research Group. A novel gene containing a trinucleotide repeat that is expanded and unstable on Huntington's disease chromosomes. Cell 1993, 72, 971-983. [CrossRef]

219. Ravina, B.; Romer, M.; Constantinescu, R.; Biglan, K.; Brocht, A.; Kieburtz, K.; Shoulson, I.; McDermott, M.P. The relationship between CAG repeat length and clinical progression in Huntington's disease. Mov. Disord. 2008, 23, 1223-1227. [CrossRef]

220. Walker, F.O. Huntington's disease. Lancet 2007, 369, 218-228. [CrossRef]

221. Ochaba, J.; Lukacsovich, T.; Csikos, G.; Zheng, S.; Margulis, J.; Salazar, L.; Mao, K.; Lau, A.L.; Yeung, S.Y.; Humbert, S.; et al. Potential function for the Huntingtin protein as a scaffold for selective autophagy. Proc. Natl. Acad. Sci. USA 2014, 111, 16889-16894. [CrossRef]

222. Rui, Y.N.; Xu, Z.; Patel, B.; Chen, Z.; Chen, D.; Tito, A.; David, G.; Sun, Y.; Stimming, E.F.; Bellen, H.J.; et al. Huntingtin functions as a scaffold for selective macroautophagy. Nat. Cell Biol. 2015, 17, 262-275. [CrossRef]

223. Shacham, T.; Sharma, N.; Lederkremer, G.Z. Protein Misfolding and ER Stress in Huntington's Disease. Front. Mol. Biosci. 2019, 6, 20. [CrossRef] [PubMed]

224. Gallardo-Orihuela, A.; Hervás-Corpión, I.; Hierro-Bujalance, C.; Sanchez-Sotano, D.; Jiménez-Gómez, G.; Mora-López, F.; Campos-Caro, A.; Garcia-Alloza, M.; Valor, L.M. Transcriptional correlates of the pathological phenotype in a Huntington's disease mouse model. Sci. Rep. 2019, 9, 18696. [CrossRef] [PubMed] 
225. Yano, H.; Baranov, S.V.; Baranova, O.V.; Kim, J.; Pan, Y.; Yablonska, S.; Carlisle, D.L.; Ferrante, R.J.; Kim, A.H.; Friedlander, R.M. Inhibition of mitochondrial protein import by mutant huntingtin. Nat. Neurosci. 2014, 17, 822-831. [CrossRef]

226. Stack, E.C.; Matson, W.R.; Ferrante, R.J. Evidence of oxidant damage in Huntington's disease: Translational strategies using antioxidants. Ann. N. Y. Acad. Sci. 2008, 1147, 79-92. [CrossRef] [PubMed]

227. Agrawal, S.; Fox, J.H. Novel proteomic changes in brain mitochondria provide insights into mitochondrial dysfunction in mouse models of Huntington's disease. Mitochondrion 2019, 47, 318-329. [CrossRef]

228. Bogdanov, M.B.; Ferrante, R.J.; Kuemmerle, S.; Klivenyi, P.; Beal, M.F. Increased vulnerability to 3-nitropropionic acid in an animal model of Huntington's disease. J. Neurochem. 1998, 71, 2642-2644. [CrossRef]

229. Brouillet, E. The 3-NP Model of Striatal Neurodegeneration. Curr. Protoc. Neurosci. 2014, 67, 9.48.1-9.48.14. [CrossRef]

230. Rosenstock, T.R.; Carvalho, A.C.; Jurkiewicz, A.; Frussa-Filho, R.; Smaili, S.S. Mitochondrial calcium, oxidative stress and apoptosis in a neurodegenerative disease model induced by 3-nitropropionic acid. J. Neurochem. 2004, 88, 1220-1228. [CrossRef]

231. Browne, S.E.; Beal, M.F. Oxidative damage in Huntington's disease pathogenesis. Antioxid. Redox Signal. 2006, 8, 2061-2073. [CrossRef]

232. Maiuri, T.; Bowie, L.E.; Truant, R. DNA Repair Signaling of Huntingtin: The Next Link Between Late-Onset Neurodegenerative Disease and Oxidative DNA Damage. DNA Cell Biol. 2019, 38, 1-6. [CrossRef] [PubMed]

233. Chen, C.M.; Wu, Y.R.; Cheng, M.L.; Liu, J.L.; Lee, Y.M.; Lee, P.W.; Soong, B.W.; Chiu, D.T. Increased oxidative damage and mitochondrial abnormalities in the peripheral blood of Huntington's disease patients. Biochem. Biophys. Res. Commun. 2007, 359, 335-340. [CrossRef] [PubMed]

234. Sánchez-López, F.; Tasset, I.; Agüera, E.; Feijóo, M.; Fernández-Bolaños, R.; Sánchez, F.M.; Ruiz, M.C.; Cruz, A.H.; Gascón, F.; Túnez, I. Oxidative stress and inflammation biomarkers in the blood of patients with Huntington's disease. Neurol. Res. 2012, 34, 721-724. [CrossRef] [PubMed]

235. Agrawal, S.; Fox, J.; Thyagarajan, B.; Fox, J.H. Brain mitochondrial iron accumulates in Huntington's disease, mediates mitochondrial dysfunction, and can be removed pharmacologically. Free Radic. Biol. Med. 2018, 120, 317-329. [CrossRef]

236. Peyser, C.E.; Folstein, M.; Chase, G.A.; Starkstein, S.; Brandt, J.; Cockrell, J.R.; Bylsma, F.; Coyle, J.T.; McHugh, P.R.; Folstein, S.E. Trial of d-alpha-tocopherol in Huntington's disease. Am. J. Psychiatry 1995, 152, 1771-1775. [CrossRef]

237. Kasparová, S.; Sumbalová, Z.; Bystrický, P.; Kucharská, J.; Liptaj, T.; Mlynárik, V.; Gvozdjáková, A. Effect of coenzyme Q10 and vitamin E on brain energy metabolism in the animal model of Huntington's disease. Neurochem. Int. 2006, 48, 93-99. [CrossRef]

238. Rebec, G.V.; Barton, S.J.; Marseilles, A.M.; Collins, K. Ascorbate treatment attenuates the Huntington behavioral phenotype in mice. Neuroreport 2003, 14, 1263-1265. [CrossRef]

239. Wright, D.J.; Gray, L.J.; Finkelstein, D.I.; Crouch, P.J.; Pow, D.; Pang, T.Y.; Li, S.; Smith, Z.M.; Francis, P.S.; Renoir, T; et al. N-acetylcysteine modulates glutamatergic dysfunction and depressive behavior in Huntington's disease. Hum. Mol. Genet. 2016, 25, 2923-2933. [CrossRef]

240. Wright, D.J.; Renoir, T.; Smith, Z.M.; Frazier, A.E.; Francis, P.S.; Thorburn, D.R.; McGee, S.L.; Hannan, A.J.; Gray, L.J. N-Acetylcysteine improves mitochondrial function and ameliorates behavioral deficits in the R6/1 mouse model of Huntington's disease. Transl. Psychiatry 2015, 5, e492. [CrossRef]

241. Sandhir, R.; Sood, A.; Mehrotra, A.; Kamboj, S.S. N-Acetylcysteine reverses mitochondrial dysfunctions and behavioral abnormalities in 3-nitropropionic acid-induced Huntington's disease. Neurodegener. Dis. 2012, 9 , 145-157. [CrossRef]

242. Andreassen, O.A.; Ferrante, R.J.; Dedeoglu, A.; Beal, M.F. Lipoic acid improves survival in transgenic mouse models of Huntington's disease. Neuroreport 2001, 12, 3371-3373. [CrossRef] [PubMed]

243. Liu, Y.; Hettinger, C.L.; Zhang, D.; Rezvani, K.; Wang, X.; Wang, H. Sulforaphane enhances proteasomal and autophagic activities in mice and is a potential therapeutic reagent for Huntington's disease. J. Neurochem. 2014, 129, 539-547. [CrossRef] [PubMed] 
244. Quinti, L.; Dayalan Naidu, S.; Träger, U.; Chen, X.; Kegel-Gleason, K.; Llères, D.; Connolly, C.; Chopra, V.; Low, C.; Moniot, S.; et al. KEAP1-modifying small molecule reveals muted NRF2 signaling responses in neural stem cells from Huntington's disease patients. Proc. Natl. Acad. Sci. USA 2017, 114, E4676-E4685. [CrossRef] [PubMed]

245. Skouta, R.; Dixon, S.J.; Wang, J.; Dunn, D.E.; Orman, M.; Shimada, K.; Rosenberg, P.A.; Lo, D.C.; Weinberg, J.M.; Linkermann, A.; et al. Ferrostatins inhibit oxidative lipid damage and cell death in diverse disease models. J. Am. Chem. Soc. 2014, 136, 4551-4556. [CrossRef] [PubMed]

246. Dodson, M.; Castro-Portuguez, R.; Zhang, D.D. NRF2 plays a critical role in mitigating lipid peroxidation and ferroptosis. Redox Biol. 2019, 23, 101107. [CrossRef] [PubMed]

247. Ellrichmann, G.; Petrasch-Parwez, E.; Lee, D.H.; Reick, C.; Arning, L.; Saft, C.; Gold, R.; Linker, R.A. Efficacy of fumaric acid esters in the R6/2 and YAC128 models of Huntington's disease. PLOS ONE 2011, 6, e16172. [CrossRef]

248. Jang, M.; Choi, J.H.; Chang, Y.; Lee, S.J.; Nah, S.Y.; Cho, I.H. Gintonin, a ginseng-derived ingredient, as a novel therapeutic strategy for Huntington's disease: Activation of the Nrf2 pathway through lysophosphatidic acid receptors. Brain Behav. Immun. 2019, 80, 146-162. [CrossRef]

249. Taroni, F.; DiDonato, S. Pathways to motor incoordination: The inherited ataxias. Nat. Rev. Neurosci. 2004, 5, 641-655. [CrossRef]

250. Koeppen, A.H. The pathogenesis of spinocerebellar ataxia. Cerebellum 2005, 4, 62-73. [CrossRef]

251. Paulson, H.L. The spinocerebellar ataxias. J. Neuroophthalmol. 2009, 29, 227-237. [CrossRef]

252. Harding, A.E. Clinical features and classification of inherited ataxias. Adv. Neurol. 1993, 61, 1-14. [PubMed]

253. Duenas, A.M.; Goold, R.; Giunti, P. Molecular pathogenesis of spinocerebellar ataxias. Brain 2006, 129, 1357-1370. [CrossRef] [PubMed]

254. Bird, T. Hereditary Ataxia Overview. Available online: http://www.geneclinics.org/servlet/access? $\mathrm{db}=$

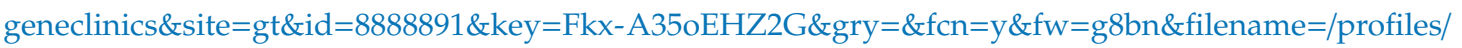
ataxias/index.html (accessed on 1 February 2020).

255. Ashizawa, T.; Oz, G.; Paulson, H.L. Spinocerebellar ataxias: Prospects and challenges for therapy development. Nat. Rev. Neurol. 2018, 14, 590-605. [CrossRef] [PubMed]

256. Paulson, H. Machado-Joseph disease/spinocerebellar ataxia type 3. Handb. Clin. Neurol. 2012, 103, 437-449. [CrossRef] [PubMed]

257. Kim, E.; Lee, Y.; Choi, S.; Song, J.-J. Structural basis of the phosphorylation dependent complex formation of neurodegenerative disease protein Ataxin-1 and RBM17. Biochem. Biophys. Res. Commun. 2014, 449, $399-404$. [CrossRef] [PubMed]

258. Carrillo-Rosas, S.; Weber, C.; Fievet, L.; Messaddeq, N.; Karam, A.; Trottier, Y. Loss of zebrafish Ataxin-7, a SAGA subunit responsible for SCA7 retinopathy, causes ocular coloboma and malformation of photoreceptors. Hum. Mol. Genet. 2018, 28, 912-927. [CrossRef]

259. Johnson, S.A.; Dubeau, L.; White, R.J.; Johnson, D.L. The TATA-binding protein as a regulator of cellular transformation. Cell Cycle 2003, 2, 442-444. [CrossRef]

260. Wang, L.; Tsai, C.-C. Atrophin proteins: An overview of a new class of nuclear receptor corepressors. Nucl. Recept Signal 2008, 6, e009. [CrossRef]

261. Lastres-Becker, I.; Nonis, D.; Eich, F.; Klinkenberg, M.; Gorospe, M.; Kotter, P.; Klein, F.A.; Kedersha, N.; Auburger, G. Mammalian ataxin-2 modulates translation control at the pre-initiation complex via PI3K/mTOR and is induced by starvation. Biochim. Biophys. Acta 2016, 1862, 1558-1569. [CrossRef]

262. Blount, J.R.; Tsou, W.-L.; Ristic, G.; Burr, A.A.; Ouyang, M.; Galante, H.; Scaglione, K.M.; Todi, S.V. Ubiquitin-binding site 2 of ataxin-3 prevents its proteasomal degradation by interacting with Rad23. Nat. Commun. 2014, 5, 4638. [CrossRef]

263. Kordasiewicz, H.B.; Gomez, C.M. Molecular pathogenesis of spinocerebellar ataxia type 6. Neurotherapeutics 2007, 4, 285-294. [CrossRef] [PubMed]

264. Crespo-Barreto, J.; Fryer, J.D.; Shaw, C.A.; Orr, H.T.; Zoghbi, H.Y. Partial loss of ataxin-1 function contributes to transcriptional dysregulation in spinocerebellar ataxia type 1 pathogenesis. PLoS Genet. 2010, 6, e1001021. [CrossRef] [PubMed]

265. Lim, J.; Hao, T.; Shaw, C.; Patel, A.J.; Szabo, G.; Rual, J.F.; Fisk, C.J.; Li, N.; Smolyar, A.; Hill, D.E.; et al. A protein-protein interaction network for human inherited ataxias and disorders of Purkinje cell degeneration. Cell 2006, 125, 801-814. [CrossRef] [PubMed] 
266. Schmidt, T.; Lindenberg, K.S.; Krebs, A.; Schols, L.; Laccone, F.; Herms, J.; Rechsteiner, M.; Riess, O.; Landwehrmeyer, G.B. Protein surveillance machinery in brains with spinocerebellar ataxia type 3: Redistribution and differential recruitment of $26 \mathrm{~S}$ proteasome subunits and chaperones to neuronal intranuclear inclusions. Ann. Neurol. 2002, 51, 302-310. [CrossRef]

267. Cummings, C.J.; Mancini, M.A.; Antalffy, B.; DeFranco, D.B.; Orr, H.T.; Zoghbi, H.Y. Chaperone suppression of aggregation and altered subcellular proteasome localization imply protein misfolding in SCA1. Nat. Genet. 1998, 19, 148-154. [CrossRef]

268. Park, Y.; Hong, S.; Kim, S.J.; Kang, S. Proteasome function is inhibited by polyglutamine-expanded ataxin-1, the SCA1 gene product. Mol. Cells 2005, 19, 23-30.

269. Hong, S.; Kim, S.-J.; Ka, S.; Choi, I.; Kang, S. USP7, a Ubiquitin-Specific Protease, Interacts with Ataxin-1, the SCA1 Gene Product. Mol. Cell. Neurosci. 2002, 20, 298-306. [CrossRef]

270. Yu, X.; Ajayi, A.; Boga, N.R.; Ström, A.-L. Differential degradation of full-length and cleaved ataxin-7 fragments in a novel stable inducible SCA7 model. J. Mol. Neurosci. 2012, 47, 219-233. [CrossRef]

271. Chai, Y.; Berke, S.S.; Cohen, R.E.; Paulson, H.L. Poly-ubiquitin binding by the polyglutamine disease protein ataxin-3 links its normal function to protein surveillance pathways. J. Biol. Chem. 2004, 279, 3605-3611. [CrossRef]

272. Zeviani, M.; Simonati, A.; Bindoff, L.A. Chapter 22-Ataxia in mitochondrial disorders. In Handbook of Clinical Neurology; Subramony, S.H., Dürr, A., Eds.; Elsevier: Amsterdam, The Netherlands, 2012; Volume 103, pp. 359-372.

273. Stucki, D.M.; Ruegsegger, C.; Steiner, S.; Radecke, J.; Murphy, M.P.; Zuber, B.; Saxena, S. Mitochondrial impairments contribute to Spinocerebellar ataxia type 1 progression and can be ameliorated by the mitochondria-targeted antioxidant MitoQ. Free Radic. Biol. Med. 2016, 97, 427-440. [CrossRef]

274. Qi, M.-L.; Tagawa, K.; Enokido, Y.; Yoshimura, N.; Wada, Y.-I.; Watase, K.; Ishiura, S.-I.; Kanazawa, I.; Botas, J.; Saitoe, M.; et al. Proteome analysis of soluble nuclear proteins reveals that HMGB1/2 suppress genotoxic stress in polyglutamine diseases. Nat. Cell Biol. 2007, 9, 402-414. [CrossRef] [PubMed]

275. Ito, H.; Fujita, K.; Tagawa, K.; Chen, X.; Homma, H.; Sasabe, T.; Shimizu, J.; Shimizu, S.; Tamura, T.; Muramatsu, S.-i.; et al. HMGB1 facilitates repair of mitochondrial DNA damage and extends the lifespan of mutant ataxin-1 knock-in mice. EMBO Mol. Med. 2015, 7, 78-101. [CrossRef] [PubMed]

276. Zhou, J.; Wang, H.; Shen, R.; Fang, J.; Yang, Y.; Dai, W.; Zhu, Y.; Zhou, M. Mitochondrial-targeted antioxidant MitoQ provides neuroprotection and reduces neuronal apoptosis in experimental traumatic brain injury possibly via the Nrf2-ARE pathway. Am. J. Transl. Res. 2018, 10, 1887-1899. [PubMed]

277. Cornelius, N.; Wardman, J.H.; Hargreaves, I.P.; Neergheen, V.; Bie, A.S.; Tumer, Z.; Nielsen, J.E.; Nielsen, T.T. Evidence of oxidative stress and mitochondrial dysfunction in spinocerebellar ataxia type 2 (SCA2) patient fibroblasts: Effect of coenzyme Q10 supplementation on these parameters. Mitochondrion 2017, 34, 103-114. [CrossRef] [PubMed]

278. Lo, R.Y.; Figueroa, K.P.; Pulst, S.M.; Lin, C.-Y.; Perlman, S.; Wilmot, G.; Gomez, C.; Schmahmann, J.; Paulson, H.; Shakkottai, V.G.; et al. Coenzyme Q10 and spinocerebellar ataxias. Mov. Disord. 2015, 30, 214-220. [CrossRef] [PubMed]

279. Paulson, H.L. Dominantly inherited ataxias: Lessons learned from Machado-Joseph disease/spinocerebellar ataxia type 3. Semin. Neurol. 2007, 27, 133-142. [CrossRef] [PubMed]

280. Yu, Y.C.; Kuo, C.L.; Cheng, W.L.; Liu, C.S.; Hsieh, M. Decreased antioxidant enzyme activity and increased mitochondrial DNA damage in cellular models of Machado-Joseph disease. J. Neurosci. Res. 2009, 87, 1884-1891. [CrossRef]

281. Laço, M.N.; Oliveira, C.R.; Paulson, H.L.; Rego, A.C. Compromised mitochondrial complex II in models of Machado-Joseph disease. Biochim. Biophys. Acta (BBA) Mol. Basis Dis. 2012, 1822, 139-149. [CrossRef]

282. Pacheco, L.S.; da Silveira, A.F.; Trott, A.; Houenou, L.J.; Algarve, T.D.; Belló, C.; Lenz, A.F.; Mânica-Cattani, M.F.; da Cruz, I.B.M. Association between Machado-Joseph disease and oxidative stress biomarkers. Mutat. Res. Genet. Toxicol. Environ. Mutagenesis 2013, 757, 99-103. [CrossRef]

283. De Assis, A.M.; Saute, J.A.M.; Longoni, A.; Haas, C.B.; Torrez, V.R.; Brochier, A.W.; Souza, G.N.; Furtado, G.V.; Gheno, T.C.; Russo, A.; et al. Peripheral Oxidative Stress Biomarkers in Spinocerebellar Ataxia Type 3/Machado-Joseph Disease. Front. Neurol. 2017, 8, 485. [CrossRef]

284. Reina, C.P.; Zhong, X.; Pittman, R.N. Proteotoxic stress increases nuclear localization of ataxin-3. Hum. Mol. Genet. 2009, 19, 235-249. [CrossRef] [PubMed] 
285. Saudou, F.; Finkbeiner, S.; Devys, D.; Greenberg, M.E. Huntingtin acts in the nucleus to induce apoptosis but death does not correlate with the formation of intranuclear inclusions. Cell 1998, 95, 55-66. [CrossRef]

286. Peters, M.F.; Nucifora, F.C.; Kushi, J.; Seaman, H.C.; Cooper, J.K.; Herring, W.J.; Dawson, V.L.; Dawson, T.M.; Ross, C.A. Nuclear Targeting of Mutant Huntingtin Increases Toxicity. Mol. Cell. Neurosci. 1999, 14, 121-128. [CrossRef] [PubMed]

287. Fujigasaki, H.; Uchihara, T.; Koyano, S.; Iwabuchi, K.; Yagishita, S.; Makifuchi, T.; Nakamura, A.; Ishida, K.; Toru, S.; Hirai, S.; et al. Ataxin-3 is translocated into the nucleus for the formation of intranuclear inclusions in normal and Machado-Joseph disease brains. Exp. Neurol. 2000, 165, 248-256. [CrossRef] [PubMed]

288. Nucifora, F.C., Jr.; Ellerby, L.M.; Wellington, C.L.; Wood, J.D.; Herring, W.J.; Sawa, A.; Hayden, M.R.; Dawson, V.L.; Dawson, T.M.; Ross, C.A. Nuclear localization of a non-caspase truncation product of atrophin-1, with an expanded polyglutamine repeat, increases cellular toxicity. J. Biol. Chem. 2003, 278, 13047-13055. [CrossRef] [PubMed]

289. Bichelmeier, U.; Schmidt, T.; Hübener, J.; Boy, J.; Rüttiger, L.; Häbig, K.; Poths, S.; Bonin, M.; Knipper, M.; Schmidt, W.J.; et al. Nuclear localization of ataxin-3 is required for the manifestation of symptoms in SCA3: In vivo evidence. J. Neurosci. 2007, 27, 7418-7428. [CrossRef] [PubMed]

290. Liguori, I.; Russo, G.; Curcio, F.; Bulli, G.; Aran, L.; Della-Morte, D.; Gargiulo, G.; Testa, G.; Cacciatore, F.; Bonaduce, D.; et al. Oxidative stress, aging, and diseases. Clin. Interv. Aging 2018, 13, 757-772. [CrossRef]

291. Klotz, L.-O.; Sánchez-Ramos, C.; Prieto-Arroyo, I.; Urbánek, P.; Steinbrenner, H.; Monsalve, M. Redox regulation of FoxO transcription factors. Redox Biol. 2015, 6, 51-72. [CrossRef]

292. Araujo, J.; Breuer, P.; Dieringer, S.; Krauss, S.; Dorn, S.; Zimmermann, K.; Pfeifer, A.; Klockgether, T.; Wuellner, U.; Evert, B.O. FOXO4-dependent upregulation of superoxide dismutase-2 in response to oxidative stress is impaired in spinocerebellar ataxia type 3. Hum. Mol. Genet. 2011, 20, 2928-2941. [CrossRef]

293. Chen, C.-M.; Weng, Y.-T.; Chen, W.-L.; Lin, T.-H.; Chao, C.-Y.; Lin, C.-H.; Chen, I.C.; Lee, L.-C.; Lin, H.-Y.; $\mathrm{Wu}$, Y.-R.; et al. Aqueous extract of Glycyrrhiza inflata inhibits aggregation by upregulating PPARGC1A and NFE2L2-ARE pathways in cell models of spinocerebellar ataxia 3. Free Radic. Biol. Med. 2014, 71, 339-350. [CrossRef]

294. Chang, K.-H.; Chen, W.-L.; Wu, Y.-R.; Lin, T.-H.; Wu, Y.-C.; Chao, C.-Y.; Lin, J.-Y.; Lee, L.-C.; Chen, Y.-C.; Lee-Chen, G.-J.; et al. Aqueous extract of Gardenia jasminoides targeting oxidative stress to reduce polyQ aggregation in cell models of spinocerebellar ataxia 3. Neuropharmacology 2014, 81, 166-175. [CrossRef] [PubMed]

295. Wu, Y.L.; Chang, J.C.; Lin, W.Y.; Li, C.C.; Hsieh, M.; Chen, H.W.; Wang, T.S.; Wu, W.T.; Liu, C.S.; Liu, K.L. Caffeic acid and resveratrol ameliorate cellular damage in cell and Drosophila models of spinocerebellar ataxia type 3 through upregulation of Nrf2 pathway. Free Radic. Biol. Med. 2018, 115, 309-317. [CrossRef]

296. Ajayi, A.; Yu, X.; Lindberg, S.; Langel, U.; Ström, A.L. Expanded ataxin-7 cause toxicity by inducing ROS production from NADPH oxidase complexes in a stable inducible Spinocerebellar ataxia type 7 (SCA7) model. BMC Neurosci. 2012, 13, 86. [CrossRef] [PubMed]

297. Boukhtouche, F.; Vodjdani, G.; Jarvis, C.I.; Bakouche, J.; Staels, B.; Mallet, J.; Mariani, J.; Lemaigre-Dubreuil, Y.; Brugg, B. Human retinoic acid receptor-related orphan receptor alpha1 overexpression protects neurones against oxidative stress-induced apoptosis. J. Neurochem. 2006, 96, 1778-1789. [CrossRef] [PubMed]

298. Friedman, M.J.; Shah, A.G.; Fang, Z.H.; Ward, E.G.; Warren, S.T.; Li, S.; Li, X.J. Polyglutamine domain modulates the TBP-TFIIB interaction: Implications for its normal function and neurodegeneration. Nat. Neurosci. 2007, 10, 1519-1528. [CrossRef]

299. Wyttenbach, A.; Sauvageot, O.; Carmichael, J.; Diaz-Latoud, C.; Arrigo, A.P.; Rubinsztein, D.C. Heat shock protein 27 prevents cellular polyglutamine toxicity and suppresses the increase of reactive oxygen species caused by huntingtin. Hum. Mol. Genet. 2002, 11, 1137-1151. [CrossRef]

300. Chen, C.-M.; Lee, L.-C.; Soong, B.-W.; Fung, H.-C.; Hsu, W.-C.; Lin, P.-Y.; Huang, H.-J.; Chen, F.-L.; Lin, C.-Y.; Lee-Chen, G.-J.; et al. SCA17 repeat expansion: Mildly expanded CAG/CAA repeat alleles in neurological disorders and the functional implications. Clin. Chim. Acta 2010, 411, 375-380. [CrossRef]

301. Lee, L.C.; Weng, Y.T.; Wu, Y.R.; Soong, B.W.; Tseng, Y.C.; Chen, C.M.; Lee-Chen, G.J. Downregulation of proteins involved in the endoplasmic reticulum stress response and Nrf2-ARE signaling in lymphoblastoid cells of spinocerebellar ataxia type 17. J. Neural Transm. 2014, 121, 601-610. [CrossRef] 
302. Koriyama, Y.; Chiba, K.; Yamazaki, M.; Suzuki, H.; Muramoto, K.; Kato, S. Long-acting genipin derivative protects retinal ganglion cells from oxidative stress models in vitro and in vivo through the Nrf2/antioxidant response element signaling pathway. J. Neurochem. 2010, 115, 79-91. [CrossRef]

303. Miyata, R.; Hayashi, M.; Tanuma, N.; Shioda, K.; Fukatsu, R.; Mizutani, S. Oxidative stress in neurodegeneration in dentatorubral-pallidoluysian atrophy. J. Neurol. Sci. 2008, 264, 133-139. [CrossRef]

304. Orr, H.T.; Zoghbi, H.Y. Trinucleotide repeat disorders. Annu. Rev. Neurosci. 2007, 30, 575-621. [CrossRef] [PubMed]

305. Hagerman, R.J.; Hall, D.A.; Coffey, S.; Leehey, M.; Bourgeois, J.; Gould, J.; Zhang, L.; Seritan, A.; Berry-Kravis, E.; Olichney, J.; et al. Treatment of fragile X-associated tremor ataxia syndrome (FXTAS) and related neurological problems. Clin. Interv. Aging 2008, 3, 251-262. [CrossRef] [PubMed]

306. Jacquemont, S.; Hagerman, R.J.; Hagerman, P.J.; Leehey, M.A. Fragile-X syndrome and fragile X-associated tremor/ataxia syndrome: Two faces of FMR1. Lancet Neurol. 2007, 6, 45-55. [CrossRef]

307. Jacquemont, S.; Hagerman, R.J.; Leehey, M.A.; Hall, D.A.; Levine, R.A.; Brunberg, J.A.; Zhang, L.; Jardini, T.; Gane, L.W.; Harris, S.W.; et al. Penetrance of the fragile X-associated tremor/ataxia syndrome in a premutation carrier population. JAMA 2004, 291, 460-469. [CrossRef]

308. Tassone, F.; Hagerman, R.J.; Chamberlain, W.D.; Hagerman, P.J. Transcription of the FMR1 gene in individuals with fragile X syndrome. Am. J. Med. Genet. 2000, 97, 195-203. [CrossRef]

309. Greco, C.M.; Hagerman, R.J.; Tassone, F.; Chudley, A.E.; Del Bigio, M.R.; Jacquemont, S.; Leehey, M.; Hagerman, P.J. Neuronal intranuclear inclusions in a new cerebellar tremor/ataxia syndrome among fragile X carriers. Brain 2002, 125, 1760-1771. [CrossRef]

310. Tassone, F.; Iwahashi, C.; Hagerman, P.J. FMR1 RNA within the intranuclear inclusions of fragile X-associated tremor/ataxia syndrome (FXTAS). RNA Biol. 2004, 1, 103-105. [CrossRef]

311. Iwahashi, C.K.; Yasui, D.H.; An, H.J.; Greco, C.M.; Tassone, F.; Nannen, K.; Babineau, B.; Lebrilla, C.B.; Hagerman, R.J.; Hagerman, P.J. Protein composition of the intranuclear inclusions of FXTAS. Brain 2006, 129, 256-271. [CrossRef]

312. Jin, P.; Duan, R.; Qurashi, A.; Qin, Y.; Tian, D.; Rosser, T.C.; Liu, H.; Feng, Y.; Warren, S.T. Pur alpha binds to $\mathrm{rCGG}$ repeats and modulates repeat-mediated neurodegeneration in a Drosophila model of fragile $\mathrm{X}$ tremor/ataxia syndrome. Neuron 2007, 55, 556-564. [CrossRef]

313. Sofola, O.A.; Jin, P.; Qin, Y.; Duan, R.; Liu, H.; de Haro, M.; Nelson, D.L.; Botas, J. RNA-binding proteins hnRNP A2/B1 and CUGBP1 suppress fragile X CGG premutation repeat-induced neurodegeneration in a Drosophila model of FXTAS. Neuron 2007, 55, 565-571. [CrossRef]

314. Ma, L.; Herren, A.W.; Espinal, G.; Randol, J.; McLaughlin, B.; Martinez-Cerdeno, V.; Pessah, I.N.; Hagerman, R.J.; Hagerman, P.J. Composition of the Intranuclear Inclusions of Fragile X-associated Tremor/Ataxia Syndrome. Acta Neuropathol. Commun. 2019, 7, 143. [CrossRef] [PubMed]

315. Ijijima, T.; Wu, K.; Witte, H.; Hanno-Iijima, Y.; Glatter, T.; Richard, S.; Scheiffele, P. SAM68 regulates neuronal activity-dependent alternative splicing of neurexin-1. Cell 2011, 147, 1601-1614. [CrossRef] [PubMed]

316. Iijima, Y.; Tanaka, M.; Suzuki, S.; Hauser, D.; Tanaka, M.; Okada, C.; Ito, M.; Ayukawa, N.; Sato, Y.; Ohtsuka, M.; et al. SAM68-Specific Splicing Is Required for Proper Selection of Alternative 3' UTR Isoforms in the Nervous System. iScience 2019, 22, 318-335. [CrossRef] [PubMed]

317. La Rosa, P.; Bielli, P.; Compagnucci, C.; Cesari, E.; Volpe, E.; Farioli Vecchioli, S.; Sette, C. Sam68 promotes self-renewal and glycolytic metabolism in mouse neural progenitor cells by modulating Aldh1a3 pre-mRNA 3'-end processing. Elife 2016, 5. [CrossRef] [PubMed]

318. Alvarez-Mora, M.I.; Rodriguez-Revenga, L.; Madrigal, I.; Guitart-Mampel, M.; Garrabou, G.; Mila, M. Impaired Mitochondrial Function and Dynamics in the Pathogenesis of FXTAS. Mol. Neurobiol. 2017, 54, 6896-6902. [CrossRef]

319. Robin, G.; Lopez, J.R.; Espinal, G.M.; Hulsizer, S.; Hagerman, P.J.; Pessah, I.N. Calcium dysregulation and Cdk5-ATM pathway involved in a mouse model of fragile X-associated tremor/ataxia syndrome. Hum. Mol. Genet. 2017, 26, 2649-2666. [CrossRef]

320. Ross-Inta, C.; Omanska-Klusek, A.; Wong, S.; Barrow, C.; Garcia-Arocena, D.; Iwahashi, C.; Berry-Kravis, E.; Hagerman, R.J.; Hagerman, P.J.; Giulivi, C. Evidence of mitochondrial dysfunction in fragile X-associated tremor/ataxia syndrome. Biochem. J. 2010, 429, 545-552. [CrossRef] 
321. Song, G.; Napoli, E.; Wong, S.; Hagerman, R.; Liu, S.; Tassone, F.; Giulivi, C. Altered redox mitochondrial biology in the neurodegenerative disorder fragile $\mathrm{X}$-tremor/ataxia syndrome: Use of antioxidants in precision medicine. Mol. Med. 2016, 22, 548-559. [CrossRef]

322. Napoli, E.; Ross-Inta, C.; Wong, S.; Omanska-Klusek, A.; Barrow, C.; Iwahashi, C.; Garcia-Arocena, D.; Sakaguchi, D.; Berry-Kravis, E.; Hagerman, R.; et al. Altered zinc transport disrupts mitochondrial protein processing/import in fragile X-associated tremor/ataxia syndrome. Hum. Mol. Genet. 2011, 20, 3079-3092. [CrossRef] [PubMed]

323. Kaplan, E.S.; Cao, Z.; Hulsizer, S.; Tassone, F.; Berman, R.F.; Hagerman, P.J.; Pessah, I.N. Early mitochondrial abnormalities in hippocampal neurons cultured from Fmr1 pre-mutation mouse model. J. Neurochem. 2012, 123, 613-621. [CrossRef]

324. Hatch, A.L.; Gurel, P.S.; Higgs, H.N. Novel roles for actin in mitochondrial fission. J. Cell. Sci. 2014, 127, 4549-4560. [CrossRef] [PubMed]

325. Pastore, A.; Tozzi, G.; Gaeta, L.M.; Bertini, E.; Serafini, V.; Di Cesare, S.; Bonetto, V.; Casoni, F.; Carrozzo, R.; Federici, G.; et al. Actin glutathionylation increases in fibroblasts of patients with Friedreich's ataxia: A potential role in the pathogenesis of the disease. J. Biol. Chem. 2003, 278, 42588-42595. [CrossRef] [PubMed]

326. Kang, M.I.; Kobayashi, A.; Wakabayashi, N.; Kim, S.G.; Yamamoto, M. Scaffolding of Keap1 to the actin cytoskeleton controls the function of Nrf2 as key regulator of cytoprotective phase 2 genes. Proc. Natl. Acad. Sci. USA 2004, 101, 2046-2051. [CrossRef] [PubMed]

327. Gakh, O.; Cavadini, P.; Isaya, G. Mitochondrial processing peptidases. Biochim. Biophys. Acta (BBA) Mol. Cell Res. 2002, 1592, 63-77. [CrossRef]

328. Condò, I.; Ventura, N.; Malisan, F.; Rufini, A.; Tomassini, B.; Testi, R. In vivo maturation of human frataxin. Hum. Mol. Genet. 2007, 16, 1534-1540. [CrossRef] [PubMed]

329. Gordon, D.M.; Shi, Q.; Dancis, A.; Pain, D. Maturation of Frataxin Within Mammalian and Yeast Mitochondria: One-Step Processing by Matrix Processing Peptidase. Hum. Mol. Genet. 1999, 8, 2255-2262. [CrossRef]

330. Schoser, B.; Timchenko, L. Myotonic dystrophies 1 and 2: Complex diseases with complex mechanisms. Curr. Genom. 2010, 11, 77-90. [CrossRef]

331. Winblad, S.; Samuelsson, L.; Lindberg, C.; Meola, G. Cognition in myotonic dystrophy type 1: A 5-year follow-up study. Eur. J. Neurol. 2016, 23, 1471-1476. [CrossRef]

332. Sansone, V.; Gandossini, S.; Cotelli, M.; Calabria, M.; Zanetti, O.; Meola, G. Cognitive impairment in adult myotonic dystrophies: A longitudinal study. Neurol. Sci. 2007, 28, 9-15. [CrossRef]

333. Schara, U.; Schoser, B.G. Myotonic dystrophies type 1 and 2: A summary on current aspects. Semin. Pediatr. Neurol. 2006, 13, 71-79. [CrossRef]

334. Machuca-Tzili, L.; Brook, D.; Hilton-Jones, D. Clinical and molecular aspects of the myotonic dystrophies: A review. Muscle Nerve 2005, 32,1-18. [CrossRef] [PubMed]

335. Liquori, C.L.; Ricker, K.; Moseley, M.L.; Jacobsen, J.F.; Kress, W.; Naylor, S.L.; Day, J.W.; Ranum, L.P. Myotonic dystrophy type 2 caused by a CCTG expansion in intron 1 of ZNF9. Science 2001, 293, 864-867. [CrossRef] [PubMed]

336. Day, J.W.; Ricker, K.; Jacobsen, J.F.; Rasmussen, L.J.; Dick, K.A.; Kress, W.; Schneider, C.; Koch, M.C.; Beilman, G.J.; Harrison, A.R.; et al. Myotonic dystrophy type 2: Molecular, diagnostic and clinical spectrum. Neurology 2003, 60, 657-664. [CrossRef] [PubMed]

337. Yum, K.; Wang, E.T.; Kalsotra, A. Myotonic dystrophy: Disease repeat range, penetrance, age of onset, and relationship between repeat size and phenotypes. Curr. Opin. Genet. Dev. 2017, 44, 30-37. [CrossRef] [PubMed]

338. Schneider, C.; Ziegler, A.; Ricker, K.; Grimm, T.; Kress, W.; Reimers, C.D.; Meinck, H.; Reiners, K.; Toyka, K.V. Proximal myotonic myopathy: Evidence for anticipation in families with linkage to chromosome 3q. Neurology 2000, 55, 383-388. [CrossRef]

339. Reddy, S.; Smith, D.B.; Rich, M.M.; Leferovich, J.M.; Reilly, P.; Davis, B.M.; Tran, K.; Rayburn, H.; Bronson, R.; Cros, D.; et al. Mice lacking the myotonic dystrophy protein kinase develop a late onset progressive myopathy. Nat. Genet. 1996, 13, 325-335. [CrossRef]

340. Wang, J.; Pegoraro, E.; Menegazzo, E.; Gennarelli, M.; Hoop, R.C.; Angelini, C.; Hoffman, E.P. Myotonic dystrophy: Evidence for a possible dominant-negative RNA mutation. Hum. Mol. Genet. 1995, 4, 599-606. [CrossRef]

341. Warf, M.B.; Berglund, J.A. MBNL binds similar RNA structures in the CUG repeats of myotonic dystrophy and its pre-mRNA substrate cardiac troponin T. RNA 2007, 13, 2238-2251. [CrossRef] 
342. Pagliarini, V.; La Rosa, P.; Sette, C. Faulty RNA splicing: Consequences and therapeutic opportunities in brain and muscle disorders. Hum. Genet. 2017, 136, 1215-1235. [CrossRef]

343. Kuyumcu-Martinez, N.M.; Wang, G.S.; Cooper, T.A. Increased steady-state levels of CUGBP1 in myotonic dystrophy 1 are due to PKC-mediated hyperphosphorylation. Mol. Cell 2007, 28, 68-78. [CrossRef]

344. Charlet, B.N.; Savkur, R.S.; Singh, G.; Philips, A.V.; Grice, E.A.; Cooper, T.A. Loss of the muscle-specific chloride channel in type 1 myotonic dystrophy due to misregulated alternative splicing. Mol. Cell 2002, 10, 45-53. [CrossRef]

345. Mateos-Aierdi, A.J.; Goicoechea, M.; Aiastui, A.; Fernández-Torrón, R.; Garcia-Puga, M.; Matheu, A.; López de Munain, A. Muscle wasting in myotonic dystrophies: A model of premature aging. Front. Aging Neurosci. 2015, 7, 125. [CrossRef] [PubMed]

346. Usuki, F.; Ishiura, S. Expanded CTG repeats in myotonin protein kinase increase susceptibility to oxidative stress. Neuroreport 1998, 9, 2291-2296. [CrossRef] [PubMed]

347. Usuki, F.; Takahashi, N.; Sasagawa, N.; Ishiura, S. Differential signaling pathways following oxidative stress in mutant myotonin protein kinase cDNA-transfected C2C12 cell lines. Biochem. Biophys. Res. Commun. 2000, 267, 739-743. [CrossRef] [PubMed]

348. Ihara, Y.; Mori, A.; Hayabara, T.; Namba, R.; Nobukuni, K.; Sato, K.; Miyata, S.; Edamatsu, R.; Liu, J.; Kawai, M. Free radicals, lipid peroxides and antioxidants in blood of patients with myotonic dystrophy. J. Neurol. 1995, 242, 119-122. [CrossRef]

349. Head, E. Oxidative damage and cognitive dysfunction: Antioxidant treatments to promote healthy brain aging. Neurochem. Res. 2009, 34, 670-678. [CrossRef]

350. Baierle, M.; Nascimento, S.N.; Moro, A.M.; Brucker, N.; Freitas, F.; Gauer, B.; Durgante, J.; Bordignon, S.; Zibetti, M.; Trentini, C.M.; et al. Relationship between inflammation and oxidative stress and cognitive decline in the institutionalized elderly. Oxid. Med. Cell. Longev. 2015, 2015, 804198. [CrossRef]

351. Michel, T.M.; Pülschen, D.; Thome, J. The role of oxidative stress in depressive disorders. Curr. Pharm. Des. 2012, 18, 5890-5899. [CrossRef]

352. Rawdin, B.J.; Mellon, S.H.; Dhabhar, F.S.; Epel, E.S.; Puterman, E.; Su, Y.; Burke, H.M.; Reus, V.I.; Rosser, R.; Hamilton, S.P.; et al. Dysregulated relationship of inflammation and oxidative stress in major depression. Brain Behav. Immun. 2013, 31, 143-152. [CrossRef]

353. Ramon-Duaso, C.; Gener, T.; Consegal, M.; Fernández-Avilés, C.; Gallego, J.J.; Castarlenas, L.; Swanson, M.S.; de la Torre, R.; Maldonado, R.; Puig, M.V.; et al. Methylphenidate Attenuates the Cognitive and Mood Alterations Observed in Mbnl2 Knockout Mice and Reduces Microglia Overexpression. Cereb. Cortex 2018, 29, 2978-2997. [CrossRef]

354. Bruna, B.; Lobos, P.; Herrera-Molina, R.; Hidalgo, C.; Paula-Lima, A.; Adasme, T. The signaling pathways underlying BDNF-induced Nrf2 hippocampal nuclear translocation involve ROS, RyR-Mediated $\mathrm{Ca}^{2+}$ signals, ERK and PI3K. Biochem. Biophys. Res. Commun. 2018, 505, 201-207. [CrossRef] [PubMed]

355. Yao, W.; Zhang, J.C.; Ishima, T.; Dong, C.; Yang, C.; Ren, Q.; Ma, M.; Han, M.; Wu, J.; Suganuma, H.; et al. Role of Keap1-Nrf2 signaling in depression and dietary intake of glucoraphanin confers stress resilience in mice. Sci. Rep. 2016, 6, 30659. [CrossRef] [PubMed]

356. Yao, W.; Zhang, J.-C.; Ishima, T.; Ren, Q.; Yang, C.; Dong, C.; Ma, M.; Saito, A.; Honda, T.; Hashimoto, K. Antidepressant effects of TBE-31 and MCE-1, the novel Nrf2 activators, in an inflammation model of depression. Eur. J. Pharmacol. 2016, 793, 21-27. [CrossRef] [PubMed]

357. Winblad, S.; Jensen, C.; Månsson, J.-E.; Samuelsson, L.; Lindberg, C. Depression in Myotonic Dystrophy type 1: Clinical and neuronal correlates. Behav. Brain Funct. 2010, 6, 25. [CrossRef]

358. Wegner, M.; Araszkiewicz, A.; Piorunska-Stolzmann, M.; Wierusz-Wysocka, B.; Zozulinska-Ziolkiewicz, D. Association between IL-6 concentration and diabetes-related variables in DM1 patients with and without microvascular complications. Inflammation 2013, 36, 723-728. [CrossRef]

359. Friedman, J.E. Anticipation in hereditary disease: The history of a biomedical concept. Hum. Genet. 2011, 130, 705-714. [CrossRef]

(C) 2020 by the authors. Licensee MDPI, Basel, Switzerland. This article is an open access article distributed under the terms and conditions of the Creative Commons Attribution (CC BY) license (http://creativecommons.org/licenses/by/4.0/). 